




\section{Governo Federal}

Ministério do Planejamento,

Desenvolvimento e Gestão

Ministro Esteves Pedro Colnago Junior

ipea

Fundação pública vinculada ao Ministério do Planejamento, Desenvolvimento e Gestão, o Ipea fornece suporte técnico e institucional às ações governamentais - possibilitando a formulação de inúmeras políticas públicas e programas de desenvolvimento brasileiros - e disponibiliza, para a sociedade, pesquisas e estudos realizados por seus técnicos.

\section{Presidente}

Ernesto Lozardo

Diretor de Desenvolvimento Institucional

Rogério Boueri Miranda

Diretor de Estudos e Políticas do Estado, das Instituições e da Democracia

Alexandre de Ávila Gomide

Diretor de Estudos e Políticas Macroeconômicas

José Ronaldo de Castro Souza Júnior

Diretor de Estudos e Políticas Regionais,

Urbanas e Ambientais

Alexandre Xavier Ywata de Carvalho

Diretor de Estudos e Políticas Setoriais de Inovação e Infraestrutura

Fabiano Mezadre Pompermayer

\section{Diretora de Estudos e Políticas Sociais}

Lenita Maria Turchi

Diretor de Estudos e Relações Econômicas e

Políticas Internacionais

Ivan Tiago Machado Oliveira

Assessora-chefe de Imprensa e Comunicação

Mylena Pinheiro Fiori

Ouvidoria: http://www.ipea.gov.br/ouvidoria

URL: http://www.ipea.gov.br
RADAR

\section{Tecnologia, produção e comércio exterior}

\author{
Editora responsável
}

Graziela Ferrero Zucoloto

Radar : tecnologia, produção e comércio exterior / Instituto de Pesquisa Econômica Aplicada. Diretoria de Estudos e Políticas Setoriais de Inovação e Infraestrutura (Diset). - n. 1 (abr. 2009) - . Brasilia : Ipea, 2009-

Quadrimestral

ISSN: 2177-1855

1. Tecnologia. 2. Produção. 3. Comércio Exterior. 4. Periódicos. I. Instituto de Pesquisa Econômica Aplicada. Diretoria de Estudos e Políticas Setoriais de Inovação e Infraestrutura (Diset).

CDD 338.005

C Instituto de Pesquisa Econômica Aplicada - ipea 2018

As publicações do Ipea estão disponíveis para download gratuito nos formatos PDF (todas) e EPUB (livros e periódicos).

Acesse: http://www.ipea.gov.br/portal/publicacoes

As opiniões emitidas nesta publicação são de exclusiva e inteira responsabilidade dos autores, não exprimindo, necessariamente, o ponto de vista do Instituto de Pesquisa Econômica Aplicada ou do Ministério do Planejamento, Desenvolvimento e Gestão.

É permitida a reprodução deste texto e dos dados nele contidos, desde que citada a fonte. Reproduções para fins comerciais são proibidas. 


\section{SUMÁRIO}

FINANCIAMENTO DO ENSINO SUPERIOR:

QUESTÕES CONCEITUAIS E A EXPERIÊNCIA INTERNACIONAL

7

Bruce Chapman

Dung Doan

LIÇÕES DO FIM DO ENSINO SUPERIOR GRATUITO NA INGLATERRA

Richard Murphy

Judith Scott-Clayton

Gillian Wyness

LIÇÕES DA TRANSIÇÃO DO CHILE PARA A GRATUIDADE NO ENSINO SUPERIOR

Jason Delisle

Andrés Bernasconi

FINANCIAMENTO ESTUDANTIL NA AUSTRÁLIA E NOS ESTADOS UNIDOS: LIÇÕES PARA O BRASIL

Paulo Meyer Nascimento

Manoela Vilela Araújo Resende

ALGUNS COMENTÁRIOS A RESPEITO DAS REFORMAS RECENTES NO FIES E OS DESAFIOS ATUAIS

Manoel Pires

A REESTRUTURAÇÃO DO FIES

Mansueto Facundo de Almeida Júnior

Alexandre Manoel Angelo da Silva

Aumara Feu

Jossifram Almeida Soares

Rodrigo Leandro de Moura

Luciano de Castro Pereira

FUNDO DE FINANCIAMENTO ESTUDANTIL (FIES):

VICISSITUDES E DESAFIOS

Vicente de Paula Almeida Júnior

Pedro Antônio Estrella Pedrosa

PRONATEC 2.0: UMA PROPOSTA DE REFORMULAÇÃO FUNDAMENTADA EM FINANCIAMENTOS

CONTINGENTES À RENDA

Paulo Meyer Nascimento

EPÍLOGO: FINANCIAMENTOS CONTINGENTES À RENDA TÊM FUTURO NO BRASIL?

Paulo Meyer Nascimento 



\section{APRESENTAÇÃO}

A ampliação do acesso ao ensino técnico e superior é preocupação vigente em diversos países, e suas experiências têm sido debatidas para aperfeiçoar as políticas públicas que visam aprimorar a sustentabilidade financeira (de universidades) e permitir que novos ingressantes alcancem esta etapa do ensino.

Financiamento estudantil é o tema da edição no 58 do boletim Radar. Serão apresentadas questóes conceituais, liçóes da experiência internacional, as reformas recentes do Fundo de Financiamento Estudantil (Fies), e as linhas gerais de uma proposta de reforma do Programa Nacional de Acesso ao Ensino Técnico e Emprego (Pronatec); permeando todos os textos estarão os financiamentos contingentes à renda.

Em Financiamento do ensino superior: questóes conceituais e a experiência internacional, Bruce Chapman e Dung Doan, além de mostrarem por que é necessária a intervenção do governo na concessão de financiamento estudantil, ainda discutem os problemas com empréstimos convencionais, as vantagens dos empréstimos com amortizações à renda futura (ECRs) e quais são as características para que seja eficaz.

As experiências de países selecionados são discutidas em três artigos: Liçôes do fim do ensino superior gratuito na Inglaterra, por Richard Murphy, Judith Scott-Clayton e Gill Wyness; Liçôes da transição do Chile para a gratuidade no ensino superior, por Jason Delisle e Andrés Bernasconi; e Financiamento estudantil na Austrália e nos Estados Unidos: liçôes para o Brasil, por Paulo Nascimento e Manoela Resende.

Passando para o caso brasileiro, três artigos discutem a evolução do Fies: Manoel Pires, em Alguns comentários a respeito das reformas recentes no Fies e os desafios atuais; Mansueto Almeida Júnior, Alexandre Silva, Aumara Feu, Jossifram Soares, Rodrigo Moura e Luciano de Castro Pereira, em A reestruturação do Fies; e Vicente Almeida Júnior e Pedro Pedrosa, em Fies: vicissitudes e desafios. Ainda, Paulo Nascimento discute instrumentos de financiamento contingente à renda para o Pronatec em Pronatec 2.0.

A síntese das principais contribuiçôes desta edição é apresentada no artigo final desta edição, elaborado por Paulo Nascimento: Financiamentos contingentes à renda têm futuro no Brasil?

A atual edição apresenta os ECRs como proposta bem-sucedida ao financiamento estudantil. Entretanto, como raramente há unanimidade em assuntos de políticas públicas, é importante sempre apresentar visôes alternativas - ou complementares. Desse modo, esta edição tem seu contraponto no no 49 do boletim Radar, no qual propostas alternativas de financiamento ao ensino superior foram debatidas. 



\section{FINANCIAMENTO DO ENSINO SUPERIOR: QUESTÕES CONCEITUAIS E A EXPERIÊNCIA INTERNACIONAL'}

Bruce Chapman²

Dung Doan ${ }^{3}$

\section{INTRODUÇÃO}

Uma política pública introduzida na Austrália em 1989 inaugurou uma transformação internacional silenciosa, mas radical, no financiamento do ensino superior. Foi naquele país, há quase trinta anos, que surgiu o primeiro programa nacional de empréstimos com amortizaçóes contingentes à renda futura (ECRs). Trata-se de um sistema em que o ensino é gratuito enquanto se faz um curso superior; em vez de serem cobradas mensalidades, exige-se o pagamento dos egressos quando e somente se a renda pessoal exceder determinado nível, limitados os pagamentos a uma proporção da renda aferida acima desse patamar.

Esse regime de reembolso distingue os ECRs da forma antes universal de empréstimos estudantis, conhecidos como empréstimos com amortizaçóes a termo (EATs), que exigem pagamentos em parcelas fixas durante um período predeterminado. Esta simples mudança tem transformado o financiamento estudantil mundo afora. ECRs de diferentes variantes existem, hoje, em outros oito países, ${ }^{4}$ na maioria das vezes substituindo EATs.

Este texto descreve os porquês da existência de programas governamentais de financiamento estudantil (seção 2), discute argumentos econômicos, administrativos e de equidade para a substituição de EATs por ECRs (seçóes 3 e 4) e conclui (seção 5) enumerando características desejáveis para que um ECR seja funcional e sustentável.

\section{POR QUE É NECESSÁRIA A INTERVENÇÃO DO GOVERNO NA CONCESSÃO DE FINANCIAMENTO ESTUDANTIL?}

A literatura econômica aponta razões tanto para haver contribuiçóes financeiras dos estudantes quanto para haver subsídios do contribuinte no financiamento do ensino superior. ${ }^{5}$ Uma questáo importante é: existe papel para o governo além de prover recursos orçamentários às instituiçôes de ensino superior (IES)?

O problema básico - e isto parece ser consenso entre economistas - é que, se deixado por conta própria, o mercado de capitais não produzirá bons resultados no financiamento do ensino superior. Isso pode ser atribuído ao fato de que investir nessa etapa de ensino é arriscado tanto para quem toma emprestado quanto para quem empresta, devido à incerteza e às informaçóes incompletas. ${ }^{6}$

1. Os autores, gentilmente, prepararam este texto para a presente edição do boletim Radar. 0 texto foi traduzido, com ajustes autorizados pelos autores, por Paulo Meyer Nascimento.

2. Professor da Australian National University (ANU).E-mail: < bruce.chapman@anu.edu.au>.

3. Pesquisadora da ANU. E-mail: <dung.doan@anu.edu.au>.

4. Nova Zelândia (1991), Inglaterra (1998), Hungria (2001), Etiópia (2002), Tailândia (2006), Coreia do Sul (2010), Holanda (2016) e Japão (2017). Desde 2017, sistemas nacionais amplos de ECR têm estado sob consideração legislativa no Brasil, na Colômbia e na Tailândia, e há debates sobre a adoção de ECR nos Estados Unidos e na Malásia.

5. BARR, N. The Welfare State as Piggy Bank. Oxford: Oxford University Press, 2001; CHAPMAN, B. Income contingent loans for higher education: international reforms. In: HANUSHEK, E. A.; WELCH, F. (Eds.). Handbook of the economics of education. Amsterdam: Elsevier, 2006. v. 2, p. $1435-1503$.

6. BARR, N. The Welfare State as Piggy Bank. Oxford: Oxford University Press, 2001; CHAPMAN, B. Income contingent loans: background. In: CHAPMAN, B.; HIGGINS, T.; STIGLITZ, J. (Eds.). Income contingent loans: theory, practice and prospects. Houndmills; New York: Palgrave Macmillan, 2014; PALACIOS, M. Investing in human capital: a capital markets approach to student funding. Cambridge: Cambridge University Press, 2007. 
Em primeiro lugar, estudantes não sabem de antemão se o curso escolhido de fato se mostrará uma boa escolha e nem mesmo se conseguirão se formar. Na Austrália, por exemplo, cerca de $20 \%$ a $25 \%$ dos estudantes matriculados acabam náo concluindo o curso. Além disso, muitos, particularmente dos estratos socioeconômicos mais baixos, podem não dispor de informação acurada sobre padrôes de renda e de empregabilidade em cada área. Essa carência de informação pode afetar a própria decisão sobre investir em um curso superior - e em que curso investir.

Em segundo lugar, mesmo se plenamente conscientes de suas capacidades e dos retornos esperados, subsistirão riscos de mercado que fogem ao controle dos estudantes. Seus retornos futuros no mercado de trabalho, que afetarão sua condição de pagar dívidas estudantis, dependem não apenas de sua capacidade, mas também das condiçóes de mercado no momento em que se formam, especificamente com relação à demanda e oferta para o tipo de formação que obtiveram.

Essas incertezas impóem riscos para mutuários e credores. Se seus rendimentos futuros se revelarem inferiores ao esperado, o mutuário não poderá vender parte do investimento para financiar um percurso educacional alternativo. Para o credor, o risco é agravado pela realidade de que, em caso de inadimplência, não há bens a serem tomados como garantia de pagamento.

Devido a esses riscos, empréstimos estudantis privados costumam estar longe do alcance da maioria, ainda mais na ausência de fiadores. Trata-se, pois, de um mercado restrito e que tende a excluir principalmente os mais pobres, alijando-os dos recursos financeiros necessários para cobrir os custos diretos e indiretos de seus estudos. Consequentemente, em quase todos os países, os governos concedem diretamente empréstimos estudantis ou afiançam empréstimos concedidos por instituiçóes financeiras.

\section{EMPRÉSTIMOS COM AMORTIZAÇÕES A TERMO (EATS): COMPROMETIMENTO EXCESSIVO DA RENDA E RISCOS DE INADIMPLÊNCIA}

Os EATs envolvem pagamento de prestaçóes fixas ao longo de um período predefinido, independentemente das circunstâncias financeiras dos devedores. Atualmente, esse tipo de empréstimo é usado para ajudar a financiar o ensino superior em muitos países, como Canadá, Chile, China, Colômbia, Filipinas, Estados Unidos e Tailândia. Um conceito fundamental que nos ajuda a entender o impacto dos empréstimos estudantis sobre o bem-estar do devedor é o encargo de reembolso (ER) - o quanto da renda é comprometida com o pagamento da dívida, ilustrando a dificuldade financeira enfrentada pelos devedores para pagar suas dívidas integralmente e no tempo.

Embora seja necessário algum sacrifício de consumo ou de poupança para pagar as prestações de um EAT (a menos que os devedores recebam apoio financeiro de outros), um ER alto pode levar devedores a dificuldades financeiras e, em casos graves, à inadimplência. Como exigem pagamentos fixos em prazo pré-determinado, os EATs geram ERs muito diferentes entre os devedores e ao longo da vida de um devedor, simplesmente devido à variaçáo em seus rendimentos. Podem aproximar-se de zero para devedores de alta renda e superar 100\% para devedores de baixa renda.

Estudos feitos em países de diferentes níveis de desenvolvimento ${ }^{7}$ têm consistentemente relatado que, durante boa parte ou até na totalidade do prazo de amortização, os $20 \%$ mais pobres entre quem tem nível superior precisariam destinar entre $40 \%$ e mais de $100 \%$ de seus ganhos para pagar dívidas estudantis financiadas por meio do EAT padrão disponível em seus países. O ônus é particularmente pesado para homens com menos de trinta anos e para mulheres de todas as idades, segmentos cujos padróes de renda costumam ser relativamente mais baixos.

7. Incluindo Brasil, China, Colômbia, Indonésia, Alemanha, Malásia, Japão, Coreia do Sul, Estados Unidos, Tailândia e Vietnã. 
Tais evidências sugerem que EATs podem criar dificuldades financeiras severas, acarretando sérios riscos de inadimplência. Comprometimentos excessivos da renda também podem repercutir em adiamentos da decisão de constituir família e de adquirir casa própria e outros bens, ou mesmo levar o devedor a fazer opçóes profissionais menos desejadas, por conta da necessidade imediata de pagar suas dívidas.

\section{EMPRÉSTIMOS COM AMORTIZAÇÕES CONTINGENTES À RENDA FUTURA (ECRs): PROTEÇÃO, EFICIÊNCIA E ACESSO}

Tendo em vista os problemas discorridos na seção anterior, que características tornam os ECRs superiores aos EATs?

\subsection{Suavização de consumo e seguro contra choques de renda}

Em contraste com os EATs, o que é fixo nos ECRs é o percentual da renda que é alocada para pagar a dívida estudantil. Os ERs de um ECR são definidos por lei e, na prática, não excedem $6 \%, 8 \%, 9 \%, 10 \%$ e $20 \%$ dos ganhos dos devedores na Hungria, na Austrália, na Inglaterra, na Nova Zelândia e na Coreia do Sul, respectivamente. Esse mecanismo demonstra que os ECR protegem os devedores de eventuais resultados ruins no mercado de trabalho, pois não há obrigaçôes de pagamento quando suas rendas são baixas, acelerando o pagamento quando o rendimento da pessoa é ou se torna alto. Nos ECRs não há a figura da inadimplência, que é inerente aos EATs.

A característica de seguro dos ECRs pode ser particularmente importante em tempos de recessão, tanto para mutuários quanto para governos. Em um EAT, perspectivas ruins de emprego no curto prazo tendem a se traduzir em altas taxas de inadimplência, comprometendo o acesso dos mutuários a outros financiamentos e reduzindo a taxa de recuperação do financiamento governamental. Esse problema é evitado com um ECR.

\subsection{Redução dos custos de transação e aumento de eficiência}

Os pagamentos de um ECR podem ser coletados de maneira barata e automática por meio de mecanismos de desconto em folha, característica rotulada de eficiência transacional. ${ }^{8}$ Esse mecanismo incorpora uma pequena responsabilidade extra aos empregadores, idêntica à retenção de impostos sobre a renda, e estima-se que, para a Austrália e a Inglaterra, os custos administrativos totais sejam inferiores a $4 \%$ das receitas anuais de seus ECRs. ${ }^{9}$ No mundo em desenvolvimento, no entanto, é comum haver parcelas significativas da população empregadas em atividades informais, dificultando o rastreamento dessas pessoas e de suas rendas no tempo e no espaço. Casos assim comprometem o bom funcionamento de um ECR, embora o nível de formalização costume ser elevado entre pessoas com educação superior, mesmo em países em desenvolvimento.

\subsection{Acesso à educação}

A principal área de investigação sobre os efeitos dos ECRs é se este tipo de financiamento contribui para promover acesso equitativo à educação superior. Pesquisas australianas revelam que, à introduçáo do ECR, seguiram-se aumentos significativos no número de matrículas. O perfil socioeconômico dos estudantes universitários australianos, contudo, permaneceu muito parecido ao observado nos anos anteriores à introdução do sistema, com algum

8. STIGLITZ, J. E. Remarks on income contingent loans: how effective can they be at mitigating risk? In: CHAPMAN, B.; HIGGINS, T.; STIGLITZ, J. E. (Eds.). Income contingent loans: theory, practice and prospects. London: Palgrave McMillan, 2014.

9. CHAPMAN, B.; HIGGINS, T.; STIGLITZ, J. E. (Eds.). Income Contingent Loans: theory, practice and prospects. London: Palgrave McMillan, 2014; HACKETT, L. HELP from down under? London: University Alliance, 2014. (University Alliance Working Paper). 
aumento na participação relativa dos segmentos situados no meio da distribuição de renda. Já na Inglaterra, as evidências empíricas mostram um efeito mais forte em termos de equidade no acesso, muito provavelmente porque o ECR inglês cobre tanto o custo das anuidades quanto o custo de vida. ${ }^{10}$

\section{CARACTERÍSTICAS DESEJÁVEIS DE UM ECR EFICAZ E SUSTENTÁVEL}

Os ECRs existentes mundo afora diferem entre si em alguns parâmetros-chave. A título de exemplo, enquanto o ECR húngaro não subsidia a taxa de juros, o neozelandês cobra taxa nominal zero, o que implica subsídios muito altos. Em todos há isenção de pagamento até certo limite de renda, mas variam bastante tanto esse limite de isenção quanto as condiçôes de pagamento para quem ganha acima dele.

A maioria dos países adota alíquotas marginais de cobrança, enquanto em outros cobra-se uma porcentagem da renda total. Os montantes de dívida não paga em países como a Inglaterra, onde a cobrança é sobre a renda marginal, são consideravelmente mais altos do que na Austrália, onde a cobrança é sobre a renda total. ${ }^{11}$ $\mathrm{Na}$ Austrália, contudo, há evidências de prática de elisão fiscal próximo ao limite superior da faixa de isenção.

Essas variaçóes implicam que não existe um sistema ideal único; para ser eficaz e sustentável, o desenho de um ECR precisa levar em conta as especificidades do país, particularmente as tocantes ao mercado de trabalho, às restrições fiscais e ao sistema de administração pública. Contudo, algumas características são desejáveis, independentemente dos detalhes do design do ECR. São elas:

- cobertura universal (para todos os matriculados), a fim de maximizar as receitas, especialmente as advindas dos reembolsos pagos por egressos com alto padrão de renda;

- desconto automático em folha, assegurando eficiência na coleta de pagamentos e, ao mesmo tempo, protegendo os devedores em momentos de resultados ruins no mercado de trabalho;

- obrigatoriedade, a fim de minimizar seleção adversa, pois ECRs facultativos tendem a atrair mais estudantes que esperam obter baixos rendimentos futuros (e consequentemente pagar menos) do que aqueles com alta expectativa de ganhos futuros, e isso acarreta dispendiosos subsídios públicos;

- no caso de ECR para financiar estudos em IES privadas, cuidado adicional se faz necessário para controle de qualidade dos cursos financiáveis e para evitar abusos de preço.

10. Ver texto Lições do fim da gratuidade do ensino superior na Inglaterra, também publicado nesta edição do Radar.

11. Nota do tradutor: vale ressaltar que as dívidas médias dos estudantes ingleses são muito maiores do que as dos estudantes australianos. Isto ocorre porque: (i) os valores que as universidades inglesas são autorizadas a cobrar dos estudantes elegíveis aos ECRs são consideravelmente mais elevados do que os valores que as universidades australianas são autorizadas a cobrar do mesmo tipo de estudante; (ii) diferentemente do sistema australiano, o inglês inclui também uma ajuda de custos para despesas cotidianas. Ver BRITTON, J.; VAN DER ERVE, L.; HIGGINS, T. Income contingent student loan design: Lessons from around the world. Economics of Education Review, no prelo. Disponível em: <https://doi.org/10.1016/j.econedurev.2018.06.001>. Acesso em: 23 jul. 2018. 


\title{
LIÇÕES DO FIM DO ENSINO SUPERIOR GRATUITO NA INGLATERRA'
}

\author{
Richard Murphy² \\ Judith Scott-Clayton ${ }^{3}$ \\ Gillian Wyness ${ }^{4}$
}

\section{INTRODUÇÃO}

Em junho de 2017, Nova Iorque tornou-se o primeiro estado dos Estados Unidos da América a oferecer a todos, exceto aos seus residentes mais ricos, matrícula gratuita em cursos superiores de quatro anos de duração, ministrados em instituições de ensino superior (IES) mantidas pelo poder público. A nova política não tornou o ensino superior totalmente gratuito, tampouco adveio sem restriçóes significativas. Ainda assim, sua introdução demonstra a força crescente do movimento em prol do ensino superior gratuito nos Estados Unidos.

Esse movimento é tipicamente associado a políticas liberais e progressistas, tendo por motivação preocupaçóes com o aumento da desigualdade e com o declínio dos investimentos em bens públicos, como a educação. Surpreende a muitos norte-americanos (e não somente a eles) escutar que o fim do ensino superior gratuito na Inglaterra teve, por trás, motivaçóes muito semelhantes.

Até 1998 havia ensino superior gratuito na Inglaterra. Duas décadas depois, a maioria das IES públicas cobra anuidade de $£ 9.250,00$ - valor $18 \%$ superior ao preço médio de um curso superior de quatro anos de duração em uma instituição pública dos Estados Unidos. ${ }^{5}$

Os defensores dessas reformas argumentavam que sistemas de ensino superior gratuitos são regressivos, uma vez que seus principais beneficiários tendem a advir das classes médias. Ressaltavam ainda que, sem recorrer a recursos privados daqueles que podiam pagar, o sistema inglês seria incapaz de atender à demanda crescente. Se mantida a gratuidade dos cursos - diziam, por fim -, as IES teriam que, ou limitar o número de vagas, ou reduzir os investimentos por aluno, possivelmente ambas as restriçôes seriam observadas concomitantemente. Os estudantes de baixa renda e as instituiçóes de menor prestígio tenderiam a sofrer as maiores consequências dessa atrofia do sistema público, exacerbando-se, assim, a desigualdade educacional.

\footnotetext{
1. Este texto é uma versão de The end of free college in England, sumário que os próprios autores fizeram de: MURPHY, R.; SCOTT-CLAYTON, J.; WYNESS, G. Lessons from the end of free college in England. Evidence Speaks Reports, v. 2, n. 13, 27 abr. 2017. Disponível em: <https://brook.gs/2xVUUf5>. Acesso em: 26 out. 2017. Tradução e adaptação: Paulo Meyer Nascimento, com autorização dos autores.

2. Professor assistente da University of Texas at Austin e pesquisador do National Bureau of Economic Research (NBER), do Centre for Economic Performance da London School of Economics and Political Science (CEP/LSE), do Institute of Labor Economics (IZA) e do CESifo Munich. E-mail: $<$ richard.murphy@austin.utexas.edu>.

3. Professora-associada de economia e educação do Teacher's College da Columbia University e pesquisadora do NBER, do Brookings Institution e do Community College Research Center (CCRC).E-mail: <scott-clayton@tc.columbia.edu>.

4. Professora de economia da educação do Institute of Education da University College of London (IoE/UCL) e pesquisadora do CEP/LSE. E-mail: <g.wyness@ucl.ac.uk>.

5. Nota do tradutor: convertendo para Real, por meio do indicador de paridade do poder de compra (PPC), disponibilizado pela Organização para a Cooperação e Desenvolvimento Econômico (OCDE), tal quantia, em valores de 2017, equivaleria a aproximadamente R\$26.250,00. 0 indicador PPC difere da taxa de câmbio porque faz a conversão levando em conta o poder de compra de cada moeda em seu país de origem, eliminando, assim, diferenças nos níveis de preço. Ver OCDE, Purchasing Power Parities (PPP). Indicador. Disponível em: <https://bit.ly/2sEQpUl>. Acesso em: 1o out. 2018.
} 


\section{POR QUE E COMO O SISTEMA INGLÊS PASSOU A SER PAGO?}

A reestruturação do seu sistema de financiamento nos últimos vinte anos levou o ensino superior inglês a retroceder ou a avançar em termos de melhoria da qualidade, quantidade e equidade? Pode-se dizer que, no mínimo, acabar com a gratuidade no ensino superior não impediu o aumento das matrículas na Inglaterra, e que os recursos por aluno (uma medida de qualidade) aumentaram substancialmente desde 1998. Além disso, após muitos anos de desigualdade crescente, as diferenças socioeconômicas no acesso ao ensino superior parecem ter estabilizado ou diminuído um pouco.

Antes de 1998, estudantes ingleses podiam cursar uma graduação de maneira completamente gratuita, desde que matriculados em tempo integral. Estudantes de baixa renda podiam, ainda, concorrer a bolsas destinadas a reduzir seu custo de vida. Mesmo quem não fosse oriundo de famílias de baixa renda tinha chances de obter pequenos empréstimos estudantis oferecidos pelo governo, a serem pagos durante um número determinado de anos subsequentes ao fim dos estudos.

Porém, à medida que a demanda por trabalhadores com nível superior aumentava, no final dos anos 1980 e durante a década de 1990, o sistema gratuito viu-se pressionado a crescer acima do ritmo para o qual estava preparado. Isso levou o governo a impor limites ao número de matrículas financiadas com recursos públicos. O investimento público por estudante caiu e, em 1998, era cerca de metade do nível médio observado nos anos 1970. Igualmente preocupante era o hiato de matrículas entre estudantes de alta e baixa renda, que chegou a 37 pontos percentuais (p.p.) para aqueles que completaram 22 anos em 1998. Foi nesse cenário que as primeiras cobranças foram introduzidas nas IES inglesas em 1998, acompanhadas de um sistema de empréstimos com amortizaçóes contingentes à renda futura (ECRs).

Os ECRs permitiam aos estudantes acessar significativamente mais recursos enquanto estavam matriculados tanto para pagar as anuidades do curso quanto para custear despesas cotidianas. Os ECRs são pagos como uma fração da renda somente depois que, já graduados, os ex-estudantes começam a trabalhar. Essas reformas mudaram completamente a estrutura do financiamento do ensino superior na Inglaterra e permitiram inúmeros aumentos subsequentes nas anuidades que as IES estavam autorizadas pelo governo a cobrar. $\mathrm{O}$ valor máximo das anuidades para estudantes domésticos passou, em 2006 , de $£ 1.000,00$ para $£ 3.000,00$ e, em 2012, para $£ 9.000,00$.

Três foram os argumentos progressistas para as reformas:

1) O novo sistema de financiamento traria mais dinheiro para as IES que enfrentavam carência de recursos, permitindo-lhes matricular mais estudantes, incluindo os menos favorecidos.

2) Exigir que os estudantes pagassem tornaria o sistema mais justo, uma vez que os principais beneficiários do ensino superior gratuito eram estudantes de famílias de classe média e alta.

3) $\mathrm{O}$ aumento dos recursos permitiria ao governo direcionar mais assistência aos mais necessitados, que muitas vezes tinham dificuldade em se manter durante o curso. A chave para isso foi a introdução dos ECRs para financiar anuidades e custo de vida, garantindo que nenhum estudante pague nada durante os estudos e ainda acesse boa quantia de recursos para sua manutençáo.

\section{O QUE MUDOU COM AS REFORMAS?}

Os progressistas estavam certos? Talvez o impacto mais óbvio das reformas tenha sido uma clara inversão das tendências de recursos disponíveis por estudante. Dois gráficos ilustram isso. $\mathrm{O}$ gráfico 1 mostra que o financiamento das IES por aluno-equivalente ${ }^{6}$ aumentou quase 50\% desde que atingiu seu nível histórico mais baixo, antes de 1998.

6. Nota do tradutor: aluno-equivalente é um indicador que pondera a quantidade de matrículas pela carga horária que seria equivalente a uma matrícula de tempo integral no curso em questão. 
Já o gráfico 2 mostra que, após a introdução de cobranças concomitantemente a um sistema de ECR, os alunos ingleses passaram a ter uma folga financeira cada vez maior durante seus estudos, pois a soma de recursos para eles disponíveis via bolsas e empréstimos cresceu mais do que os pagamentos que lhes eram exigidos durante o curso.

\section{GRÁFICO 1}

Financiamento por aluno-equivalente nas IES inglesas (1961-2014)

(Em f)

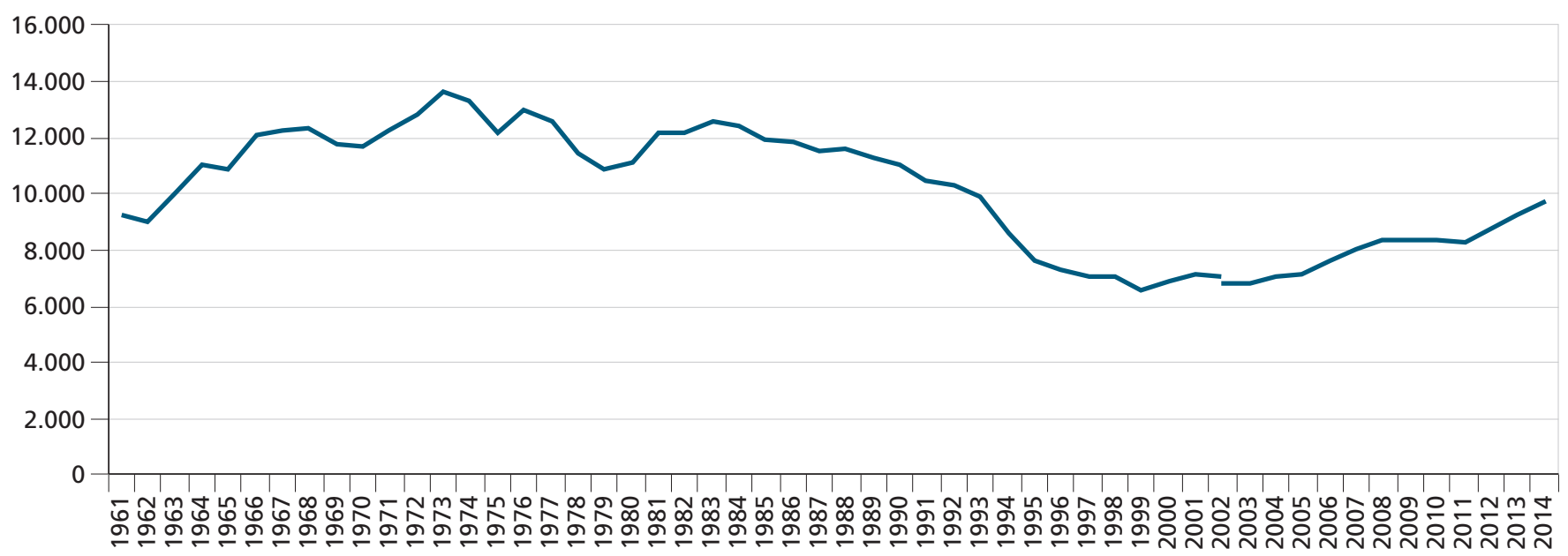

Fontes: Carpentier (2004) (para série até 2002); cálculo dos autores com dados de Higher Education Information Database for Institutions (para série a partir de 2003). Elaboração dos autores.

\section{GRÁFICO 2}

Liquidez, medida como a diferença entre recursos disponíveis via empréstimos e bolsas oferecidas pelo governo e o total de pagamentos exigidos durante o curso, para estudantes ingleses de três diferentes níveis de renda familiar (1991-2015) $(\mathrm{Em} \mathrm{f})$

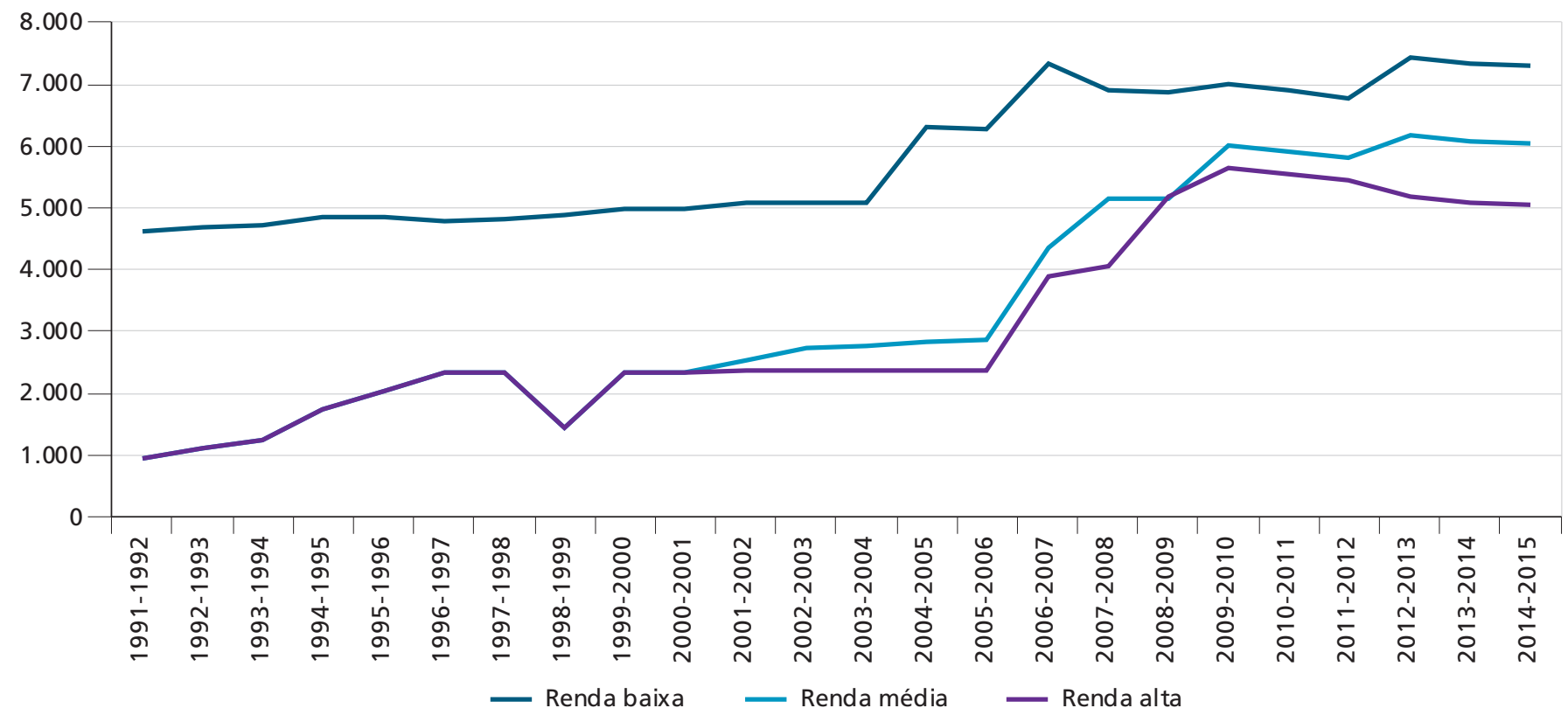

Fonte: Student Loans Company. Disponível em: <https://www.slc.co.uk/>. 
Teria isso acontecido conjuntamente a declínios das matrículas e aumento da desigualdade? Não. As taxas de matrícula quase que dobraram desde a reforma de 1998. O ritmo de crescimento das matrículas é mais intenso entre estudantes oriundos dos estratos socioeconômicos mais baixos, de forma que, embora ainda seja grande, a lacuna no acesso entre os grupos de renda mais alta e de renda mais baixa tem se mantido estável ou com alguma queda. Assim, embora seja difícil saber o que teria acontecido na ausência das reformas, parece que o novo sistema na Inglaterra cumpriu seus objetivos progressistas, expandindo, de maneira inclusiva, o acesso ao ensino superior naquele país.

\section{QUEM PAGA E QUEM SE BENEFICIA? ${ }^{8}$}

A tabela 1 descreve a posição líquida de cada uma das quatro partes interessadas após cada ciclo de mudanças desde a introdução dos ECR na Inglaterra:

- contribuintes: financiam o sistema por meio de repasses às IES e de subsídios aos ECRs;

- graduados: também financiam o sistema ao reembolsarem os ECRs que custearam seus estudos;

- universidades: são beneficiários líquidos, recebendo do governo as transferências diretas e o valor das anuidades;

- estudantes: também beneficiários líquidos, recebendo os ECRs que financiam as anuidades de seus cursos e as bolsas e os ECRs que ajudam a custear suas despesas cotidianas.

\section{TABELA 1}

Fluxos anuais do financiamento do ensino superior da Inglaterra

(Em $\mathrm{f}$ bilhões)

\begin{tabular}{|c|c|c|c|c|}
\hline & 1997-1998 & 2011-2012 & $2012-2013$ & $2017-2018$ \\
\hline \multicolumn{5}{|c|}{ Fontes de financiamento } \\
\hline Governo & 5,4 & 9,1 & 8,0 & 6,3 \\
\hline Egressos & 0,7 & 6,3 & 11,0 & 12,2 \\
\hline \multicolumn{5}{|c|}{ Destinatários do financiamento } \\
\hline IES & 4,1 & 7,7 & 11,2 & 10,7 \\
\hline Estudantes & 2,0 & 7,8 & 7,9 & 7,9 \\
\hline
\end{tabular}

Fonte: Ajustado pelos autores a partir de tabela publicada em Murphy, Scott-Clayton e Wyness (2018). ${ }^{9}$

Obs.: Valores de 2016

Como mostra a tabela 1, o total de recursos que fluem para o ensino superior aumentou substancialmente desde o fim da gratuidade, em 1998. O crescimento das contribuiçóes dos graduados desde 2012 (já cobrem dois terços do custo de sua formação) vem casado com diminuição de aportes públicos. Isso ocorre porque os repasses governamentais foram bastante reduzidos em 2012, de modo que a maior parte do dinheiro público para as universidades hoje vem dos subsídios aos ECRs. Em termos absolutos, há mais dinheiro público para as universidades atualmente do que na época em que ensino superior era gratuito na Inglaterra. Mesmo com a redução do valor de financiamento público por aluno, cresceram as matrículas e os subsídios públicos aos ECRs.

As universidades viram crescer seus orçamentos, embora o congelamento do valor real das anuidades entre 2012 e 2017 tenha diminuído um pouco seus ganhos. Os estudantes têm sido os principais beneficiários

8. Esta seção baseia-se no artigo completo (não na versão traduzida) e foi gentilmente inserida pelos autores, a pedido do tradutor.

9. MURPHY, R.; SCOTT-CLAYTON, J.; WYNESS, G. The end of free college in England: implications for quality, enrolments, and equity. Cambridge: NBER, 2018. (NBER Working Paper, n. 23888). Disponível em: <https://bit.ly/2xQZUDU>. Acesso em: 25 mar. 2018. 
das reformas: dispóem, hoje, de quatro vezes mais apoio financeiro do que tinham na época da gratuidade. Uma das principais consequências das reformas tem sido permitir que os estudantes acessem maiores parcelas de suas rendas futuras para financiar suas despesas presentes.

\section{QUAIS AS IMPLICAÇÕES PARA O DEBATE SOBRE GRATUIDADE NO ENSINO SUPERIOR?}

Em primeiro lugar, este estudo mostra que os aumentos significativos nos custos do ensino superior para os estudantes ingleses foram, sem exceção, acompanhados de aumentos semelhantes, ou até maiores, nos montantes de ajuda estudantil. Portanto, não basta olhar apenas os custos que recaem sobre estudantes de ensino superior. Mais importante é garantir-lhes recursos para viabilizar seus estudos. Embora o ensino superior não seja mais gratuito na Inglaterra, não é exigido nenhum desembolso dos estudantes durante o curso, sendo o pagamento das anuidades diferido para depois da formatura. Mesmo com os sucessivos aumentos no valor das anuidades, os estudantes têm, hoje, acesso a mais recursos para financiar seus estudos do que tinham no passado.

Em segundo lugar, o sistema de financiamento estudantil da Inglaterra, que é contingente à renda futura, possibilita que os estudantes façam empréstimos com segurança para pagar as anuidades e para custear suas despesas cotidianas. Paga-se, depois de formado, uma fraçáo do rendimento auferido acima de um patamar mínimo. Os pagamentos são descontados automaticamente dos salários dos egressos do ensino superior. Ao mesmo tempo em que oferece ao estudante a segurança de saber que só pagará se vier a futuramente dispor de renda compatível para isso, o ECR minimiza o risco de não pagamento, colocando-se como um sistema relativamente barato e bastante eficiente de financiamento estudantil.

Finalmente, a experiência da Inglaterra, desde as reformas de 1998, ilustra claramente os riscos de um sistema de ensino superior totalmente gratuito: $i$ ) financiamento público insuficiente leva ao declínio da qualidade e a uma baixa capacidade de ampliação de vagas; e ii) ensino gratuito para todos significa menos dinheiro para ajudar os alunos mais necessitados com as tantas outras despesas em que incorrem. Essas podem ser as consequências reais da gratuidade introduzida no Estado de Nova Iorque: como nenhum financiamento adicional está sendo previsto para as IES, aumenta-se a probabilidade de que os recursos por aluno caiam à medida que as matrículas aumentem. ${ }^{10}$

Nenhum modelo é isento de desafios. No entanto, a experiência inglesa sugere que manter a gratuidade para todos não é o único caminho para aumentar a quantidade, a qualidade e a equidade no ensino superior. Pelo contrário, gratuidade irrestrita pode, às vezes, trabalhar contra esses objetivos. 



\section{LIÇÕES DA TRANSIÇÃO DO CHILE PARA A GRATUIDADE NO ENSINO SUPERIOR ${ }^{1}$}

Jason Delisle ${ }^{2}$

Andrés Bernasconi ${ }^{3}$

\section{INTRODUÇÃO}

Mensalidades existem em universidades públicas e privadas no Chile e estão entre as mais altas do mundo: o valor médio equivale a aproximadamente duas vezes a renda familiar per capita. Apenas as universidades privadas americanas e as universidades britânicas cobram valores proporcionalmente mais altos. No preço médio não estão inclusos subsídios do governo nem bolsas de estudo, que podem reduzir significativamente o montante efetivamente pago pelos estudantes. Não obstante, gratuidade no ensino superior tornou-se uma ideia popular no Chile após os protestos estudantis ocorridos em 2011, quando estudantes foram às ruas contestar as cobranças nas universidades, a alta dívida estudantil e a grande concentração de matrículas em instituiçóes privadas nas quais $85 \%$ dos estudantes de ensino superior chilenos estáo matriculados.

Em resposta aos protestos de 2011, o parlamento chileno aprovou em 2016 uma política de isenção de cobrança em cursos superiores. Entretanto, a política de gratuidade não é tão abrangente quanto possa parecer; incluíram-se vários mecanismos para limitar seu custo e seu escopo. Nem todas as instituiçóes de ensino superior (IES) são elegíveis e outras optaram por não participar. Além disso, o benefício é restrito a estudantes de baixa e média renda, muitos dos quais já tinham acesso a abrangentes bolsas do governo. De todo modo, em um primeiro momento expandiu-se acesso para estudantes de baixa renda, pois, diferentemente dos critérios para obtenção de bolsas e empréstimos, não lhes é exigido desempenho mínimo em exames nacionais para terem direito à gratuidade. As universidades públicas, que compulsoriamente participam da nova política de financiamento, assim como algumas das IES privadas que voluntariamente aderiram e oferecem vagas gratuitas, argumentam que as dotaçóes do governo não são suficientes para compensar a perda de receita e cobrir os custos do ensino. Evidências empíricas sugerem que, se o processo de universalização da gratuidade não vier acompanhado de grande investimento para expandir vagas, estudantes de baixa renda poderão vir a ter maiores dificuldades de acesso do que antes da gratuidade, principalmente nos cursos mais concorridos.

\section{A TRANSIÇÃO PARA A GRATUIDADE NO CHILE}

Tornar o ensino superior gratuito foi parte central da plataforma que, em 2013, elegeu Michelle Bachelet presidente do Chile. Com o compromisso de universalizá-la até 2020, prometeu-se viabilizar, até 2018, a gratuidade para estudantes cuja renda familiar estivesse entre as $70 \%$ mais baixas do país. Eleita com $62 \%$ dos votos e dispondo de maiorias confortáveis na Câmara e no Senado, Bachelet saiu das urnas com clara legitimidade para implementar a gratuidade. Entretanto, a efetivação da promessa rapidamente revelou-se bastante desafiadora.

\footnotetext{
1. Este texto é uma versão de DELISLE, J.; BERNASCONI, A. Lessons from Chile's transition to free college. Evidence Speaks Reports, v. 2, n. 43, 15 mar. 2018. Disponível em: <https://brook.gs/20qfqyO>. Acesso em: 25 mar. 2018. Os autores autorizaram a tradução e as adaptações feitas para o formato e a linguagem do boletim Radar. Tradução e adaptação: Paulo Meyer Nascimento.

2. Pesquisador do American Enterprise Institute (AEI). E-mail: <jason.delisle@aei.org>.

3. Professor titular da Faculdade de Educação da Pontifícia Universidade Católica de Chile.E-mail: <abernasconi@uc.cl>.
} 
Confrontado com o alto custo da gratuidade e com arrecadação abaixo do esperado, o governo de Bachelet precisou optar por um plano mais gradual de implementação da política. Inicialmente, o direito à gratuidade no ensino superior circunscreveu-se às famílias situadas na metade mais pobre da distribuição de renda. Diferentemente da promessa de campanha, em 2018 estendeu-se o benefício somente até os estudantes oriundos das $60 \%$ mais pobres famílias chilenas. A legislação em vigor prevê ampliar automaticamente o limite de renda sempre que as receitas fiscais atingirem patamares preestabelecidos.

Todas as IES públicas são obrigadas a aderir à gratuidade. Faculta-se a adesão às IES privadas sem fins lucrativos e credenciadas como de alto padrão. $\mathrm{O}$ valor que o governo paga por cada matrícula gratuita depende do curso e do tipo de IES, sendo baseado no preço médio praticado antes da nova política por cada categoria de IES para cada curso. A gratuidade é garantida somente para a duração oficial do curso. Na prática, contudo, os cursos costumam durar de $10 \%$ a $50 \%$ mais tempo do que o prazo oficial. Alunos de instituiçóes não participantes ou cuja renda familiar esteja acima do limite que garante gratuidade podem solicitar ao governo bolsas de estudo ou empréstimos subsidiados.

\section{O ALCANCE DA MEDIDA}

Os manifestantes de 2011 e a ex-presidente Bachelet defenderam a gratuidade em parte por razóes filosóficas e éticas - a visão do ensino superior como um direito, devendo, por isso, ser gratuito. As estatísticas descritivas, contudo, mostram que a política está muito aquém de garantir ensino superior gratuito universal.

Nem todas as universidades participam da política de gratuidade. Em 2016, primeiro ano de gratuidade, apenas trinta universidades, das sessenta que atuam no Chile, participaram. Algumas não cumprem os requisitos, mas pelo menos três IES privadas elegíveis optaram por não participar.

Mesmo que todas participassem, a gratuidade não seria universal. O corte de renda reduz bastante seu alcance, como também o fato de muitas IES não serem elegíveis (por terem fins lucrativos ou status menor de credenciamento) ou simplesmente preferirem não participar. A política beneficiava apenas $12 \%$ dos alunos de graduação em 2016 (aproximadamente 140 mil pessoas). Em 2017, passou a beneficiar 22\%, em parte graças à inclusão, a partir daquele ano, de institutos profissionais e de centros de treinamento técnico, onde estavam 36\% das matrículas gratuitas registradas em 2017.

\section{A GRATUIDADE SUBSTITUI BOLSAS E EMPRÉSTIMOS ESTUDANTIS}

De acordo com o Ministério da Educação do Chile, 87\% dos não ingressantes que passaram a usufruir da gratuidade em 2016 recebiam algum tipo de ajuda financeira do governo em 2015. Em outras palavras, apenas 13\% dos beneficiários da gratuidade que já eram estudantes universitários não dispunham de nenhuma assistência anteriormente. Assim foi porque, mesmo antes das mudanças de 2016, estudantes oriundos de famílias situadas entre as 50\% mais pobres do Chile qualificavam-se para ajuda governamental, na forma de bolsas e de empréstimos subsidiados.

Inicialmente, a gratuidade aumentou o financiamento público para alguns estudantes de baixa renda, por dois motivos. Primeiro, porque nem todas as bolsas eram efetivamente integrais e os empréstimos, ainda que subsidiados, posteriormente precisariam ser reembolsados. ${ }^{4}$ Segundo, porque os requisitos de mérito acadêmico, exigidos para

4. Nos anos que antecederam à gratuidade, a Organização para a Cooperação e o Desenvolvimento Econômico (OCDE) e o Banco Mundial estimaram que o valor médio de bolsa para estudantes de baixa renda cobria entre $63 \%$ e $70 \%$ do custo real das mensalidades. A diferença era paga diretamente pelos estudantes ou financiada por meio de empréstimos subsidiados. 
a concessão de bolsas e de empréstimos subsidiados, não são condição para fazer valer o direito à gratuidade. Havia quem passava nos processos seletivos de algumas das IES que, hoje, têm vagas gratuitas, mas não cumpriam os requisitos de desempenho acadêmico à época exigidos para a obtenção de bolsas ou mesmo de empréstimos subsidiados pelo governo. Com efeito, as três instituiçôes que mais tiveram matrículas gratuitas em 2016 são as menos seletivas das trinta participantes da política de gratuidade. A maioria de seus alunos não conseguiu outras formas de ajuda financeira no passado, pois não teria atingido os padrôes acadêmicos então exigidos.

É possível que o governo alcançasse os mesmos resultados se, ao invés de aprovar as reformas legislativas que introduziram a gratuidade, simplesmente tivesse retirado as exigências de mérito para a concessão de suas bolsas de estudo. Na maioria das vezes, a gratuidade tem meramente substituído outras formas de auxílio estudantil.

\section{POSSÍVEIS EFEITOS INDESEJÁVEIS DA GRATUIDADE}

Defensores da gratuidade argumentam que o ensino gratuito e a remoção dos requisitos de mérito permitiriam que mais estudantes de baixa renda se matriculassem. O Ministério da Educação chileno afirma que isso de fato

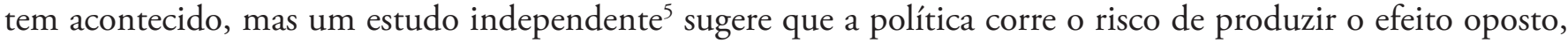
a médio e longo prazos.

Observando mudanças no perfil socioeconômico dos discentes após o ciclo anterior de reformas no financiamento estudantil, o estudo em questão alerta para dois possíveis efeitos futuros indesejáveis da política chilena de gratuidade. Um, a redução do acesso dos mais pobres ao ensino superior. Dois, a concentração de alunos mais pobres em cursos e IES de menor prestígio.

O autor usa registros administrativos do Ministério da Educação e sugere que a expansão da elegibilidade a bolsas de estudo para estudantes de famílias com renda de classe média em 2012 (quatro anos antes da gratuidade) aumentou a demanda por ensino superior mais do que a oferta, fazendo com que as IES se tornassem mais seletivas e passassem a admitir alunos com pontuaçôes mais altas nos exames de ingresso. Como os estudantes de renda mais baixa tendem a ter pontuaçóes menores nesses exames, começaram a ocupar menos vagas nas melhores universidades depois que a classe média passou a ter acesso às bolsas de estudos dadas pelo governo. $\mathrm{O}$ autor então simula quão grande tal efeito poderia ser quando a gratuidade viesse a ser universalizada.

Os resultados apontam para um declínio esperado de $20 \%$ no número de matrículas de estudantes de baixa renda, em comparação com o número observado antes da gratuidade. Isso ocorreria à medida que aumentasse a presença de alunos mais ricos nos processos seletivos mais concorridos, deslocando alguns dos bons estudantes mais pobres para processos seletivos menos concorridos. Por fim, alguns dos alunos mais pobres que antes tenderiam a conseguir vaga nos cursos de menor prestígio acabariam fora do ensino superior ante a concorrência com candidatos mais qualificados que deixaram de ser competitivos nos cursos mais procurados.

$\mathrm{O}$ autor do estudo explica que esse efeito poderia ser mitigado por uma grande expansão na capacidade das IES chilenas. Ironicamente, porém, a política de gratuidade tende a inviabilizar isso, podendo até mesmo dificultar a própria manutenção das condiçôes de ensino existentes.

Sob a política de gratuidade, o governo chileno paga mensalidades em nome de cada aluno elegível matriculado. Para muitas IES, o valor pago pelo governo é substancialmente menor do que o preço efetivamente cobrado dos alunos pagantes. Como não é mais possível cobrar dos estudantes a diferença entre o valor do curso e o auxílio estudantil dado pelo governo, a perda de receita precisará ser compensada de algum modo. Os reitores de algumas dessas universidades estão chamando a atenção para o aperto do financiamento e suas consequências. Mesmo que as IES encontrem economias de escala na matrícula de mais estudantes, há no desenho da política uma restrição que

5. BUCAREY, A. Who pays for free college? Crowding out on campus. Cambridge: MIT, 2018. Disponível em: <https://bit.ly/2zm4Lht>. Acesso em: 25 mar. 2018. 
limita o crescimento de matrículas a 2,7\% ao ano. Queda de investimento, perda de qualidade e baixo crescimento de vagas desenham-se, portanto, como cenários bastante plausíveis.

\section{CONCLUSÃO}

O Chile pode estar buscando o ideal do ensino superior gratuito, mas até agora o efeito prático tem sido limitado e repleto de consequências indesejáveis. Em vez de propiciar ensino superior universalmente gratuito, a nova política substitui um sistema de financiamento compartilhado (via mensalidades) aliado a ajuda financeira focalizada (via bolsas e empréstimos subsidiados) por um sistema de financiamento estudantil menos focalizado e mais dependente de recursos públicos. O benefício incremental para estudantes de baixa renda que antes recebiam bolsas de estudo e empréstimos altamente subsidiados é indiscutivelmente pequeno, e os estudantes de renda mais alta continuarão pagando mensalidades.

Talvez a mudança mais significativa seja que a gratuidade não impóe requisitos de mérito, o que permite a mais estudantes de baixa renda beneficiarem-se da ajuda do governo. No entanto, ainda é cedo para saber em que medida a gratuidade sustentará esse efeito. Estudo recente prevê posterior declínio na matrícula de estudantes de baixa renda, caso as universidades chilenas mostrem-se incapazes de expandir consistentemente sua oferta sob o novo sistema.

Mesmo que efeitos regressivos da gratuidade sejam evitados, sua adoção sem aumento compatível do financiamento público compromete o investimento e a manutenção da qualidade do ensino, preocupação raramente presente nos debates sobre a gratuidade. Como mostra o caso do Chile, as universidades de maior prestígio do país (que têm as estruturas de custo mais altas) agora enfrentam deficits orçamentários por causa da gratuidade. Provavelmente terão que cortar gastos para compensar o declínio da receita, mas só será possível avaliar os efeitos completos da gratuidade no Chile nos próximos anos, à medida que mais dados estiverem disponíveis.

Existem alguns exemplos remanescentes de países que mantêm sistemas de ensino superior gratuitos; a maioria, porém, adota ou tem caminhado em direção a modelos de financiamento compartilhado, em que os custos do ensino são divididos entre o Estado e os beneficiários diretos da formaçáo superior. Esses modelos parecem equilibrar melhor preço, acesso e qualidade, fatores que afetam o sucesso do sistema de ensino superior de um país. Caso a gratuidade no Chile ${ }^{6}$ se mostre fiscalmente sustentável e ainda consiga aumentar o acesso e mitigar as consequências náo intencionais, será esta uma exceçáo notável de caso em que o financiamento 100\% público produz resultados melhores do que o financiamento compartilhado aliado a auxílio focalizado. 


\section{FINANCIAMENTO ESTUDANTIL NA AUSTRÁLIA \\ E NOS ESTADOS UNIDOS: LIÇÕES PARA O BRASIL ${ }^{1}$}

Paulo Meyer Nascimento²

Manoela Vilela Araújo Resende ${ }^{3}$

\section{INTRODUÇÃO}

Brasil, Austrália e Estados Unidos são países que guardam grandes diferenças entre si, mas também algumas similaridades. Os três são repúblicas federativas, grandes economias e naçôes com alto grau de diversidade étnica e cultural. Para fins de políticas de ensino superior, contudo, a maior similaridade está no fato de que nos três há grande protagonismo do governo federal em questôes de financiamento e de regulação. Este fato facilita a comparaçáo dos sistemas de financiamento de estudantes de ensino superior dos três países, destacando suas respectivas peculiaridades e discutindo em que medida a experiência de cada um deles pode ser relevante para os outros dois.

Tendo por foco o financiamento do ensino, ${ }^{4}$ o objetivo deste texto é discutir quais características dos sistemas federais australiano e norte-americano poderiam inspirar inovaçóes no sistema brasileiro e quais deveriam ser evitadas. Em busca desse objetivo, a seção 2 e o apêndice fornecem um sumário dos modelos vigentes no Brasil, na Austrália e nos Estados Unidos para financiar estudantes de ensino superior, para, daí, serem discutidas, na seção 3, também de maneira sucinta, as liçôes advindas dos dois modelos estrangeiros que poderiam ser aproveitadas no Brasil.

\section{COMPARANDO OS TRÊS SISTEMAS}

Quando falamos de financiamento de estudantes de ensino superior no Brasil imaginam-se, logo, programas de bolsa ou de empréstimos para ajudar estudantes carentes a pagar as mensalidades de cursos superiores em instituiçóes privadas de ensino. Esse é o pensamento que aflora de imediato porque, aqui, o ensino superior é gratuito em instituiçóes públicas 5 e porque é recorrente o debate sobre iniciativas governamentais como o Programa Universidade para Todos (Prouni) e o Programa de Financiamento Estudantil (Fies); o primeiro é um programa de bolsas, enquanto o segundo é um programa de crédito educativo, ambos desenhados para estudantes oriundos de famílias de baixa renda matriculados em cursos superiores pagos.

\footnotetext{
1. Este texto é uma versão resumida de um capítulo de livro (atualmente no prelo). Os autores agradecem à professora doutora Ana Maria de Albuquerque Moreira, do Departamento de Planejamento e Administração da Faculdade de Educação (PAD/FE) da Universidade de Brasília (UnB), pelo convite e pelo estímulo para que o produzissem a partir de suas pesquisas de doutorado (no caso de Paulo Meyer Nascimento) e de mestrado (no caso de Manoela Vilela Araújo Resende). Ressalte-se que as opiniões expressadas ao longo deste texto, bem como eventuais erros e omissões, são de inteira e exclusiva responsabilidade dos autores, não refletindo necessariamente posicionamento das instituições públicas das quais são servidores.

2. Técnico de planejamento e pesquisa na Diretoria de Estudos e Políticas Setoriais de Inovação e Infraestrutura (Diset) do Ipea. E-mail: < paulo.nascimento@ipea.gov.br>.

3. Analista técnico de políticas sociais no Ministério da Educação (MEC), atuando, em 2018, na Assessoria Estratégica de Evidências, no Gabinete do Ministro. E-mail: <manoelaaraujo@mec.gov.br>.
}

4. 0 financiamento à pesquisa, conquanto igualmente importante, não é objeto deste texto.

5. À exceção das instituições públicas que já cobravam mensalidades quando da promulgação da Constituição Federal de 1988 (CF/88). 
Tal qual no Brasil, bolsas e empréstimos são as modalidades de financiamento estudantil presentes mundo afora. Diferentemente do Brasil, contudo, cursos em instituiçôes de ensino superior (IES) públicas não são necessariamente gratuitos em outros países. Pelo contrário; o mais comum é exigir algum tipo de contribuição financeira de quem estuda, seja durante o curso, seja após a formatura.

Nos Estados Unidos e na Austrália, as IES públicas podem cobrar por seus cursos de graduação, o que não significa que não recebam aportes de recursos públicos. Isso ocorre nos Estados Unidos de variadas maneiras, a depender do ente federativo a que cada IES está vinculada e da sua capacidade para captar recursos externos. Já na Austrália, aportes públicos sobrevêm tanto por meio de repasses orçamentários diretos (tabelados por curso e proporcionais ao número de matrículas) quanto por meio de subsídios às contribuiçóes financeiras dos egressos. Seja nas públicas, seja nas privadas, norte-americanos e australianos cursando ensino superior dispóem de alternativas de financiamento público.

Via de regra, IES norte-americanas são livres para definir o valor das anuidades de seus cursos. Diversas modalidades de bolsas e empréstimos coexistem, alocadas por meio de um complexo sistema que, embora centralizado no nível federal, depende também de decisóes das IES e exige do estudante interessado, por vezes recorrentemente, grande número de informaçôes pessoais e familiares.

Já o sistema de financiamento estudantil australiano é bem mais simples e envolve unicamente empréstimos com amortizaçôes contingentes à renda futura (ECRs), com algumas variaçôes a depender da modalidade de ensino (profissional ou superior), da natureza administrativa da IES (pública ou privada) e do tipo de despesa financiada (anuidades do curso, outras taxas ou participação em programas de intercâmbio). O governo australiano estipula os valores máximos das anuidades de cada curso de IES pública e estabelece um limite para a quantia que estudantes de IES privadas podem tomar emprestado. O governo paga às IES no ato da matrícula, para depois o órgáo australiano equivalente à Receita Federal recolher pagamentos contingentes à renda do indivíduo, até que seja zerado seu saldo devedor, sendo perdoadas as dívidas estudantis porventura remanescentes em caso de morte. As taxas de juros dos empréstimos são subsidiadas na Austrália, mas em regra não o são nos Estados Unidos.

Por sua vez, no Brasil são diversos os sistemas públicos de financiamento de estudantes de ensino superior. A Uniâo, a maioria dos estados e alguns poucos municípios tanto ofertam vagas de ensino superior (por meio de suas IES) quanto financiam estudantes matriculados em cursos pagos. No caso da União, há ainda os subsídios na forma de restituições de imposto de renda para despesas privadas com educação. Apesar da atuação também de estados e municípios, há um protagonismo da União no financiamento público do ensino superior no Brasil, pois mantém as instituiçóes federais e opera políticas que geram subsídios para as privadas e eventualmente viabilizam recursos federais para IES estaduais e municipais.

Para estudantes matriculados em IES estaduais ou federais, a matrícula é $100 \%$ custeada por orçamentos públicos (respectivamente dos estados e da Uniáo). Costuma haver, ainda, alguma provisão orçamentária específica e bastante limitada, dos governos ou das próprias IES, para oferecer alimentação, alojamento e transporte subsidiados, preferencialmente a estudantes de baixa renda. Para estudantes matriculados nas IES privadas, o Fies ${ }^{6}$ o Prouni são os principais programas governamentais de assistência financeira.

\section{QUE LIÇÕES DOS SISTEMAS DA AUSTRÁLIA E DOS ESTADOS UNIDOS PODERIAM SER TIRADAS PARA O BRASIL?}

Há, nos sistemas federais de financiamento de estudantes do ensino superior da Austrália e dos Estados Unidos, tanto características positivas quanto negativas. Um olhar sobre elas pode trazer liçóes pertinentes ao Brasil, não apenas sobre o que fazer, mas, principalmente, sobre o que evitar. 
O aspecto positivo que mais merece atenção é o modelo de financiamento contingente à renda futura. O sistema australiano já funciona há trinta anos e tem demonstrado que, quando de ampla cobertura, com gestão centralizada e envolvendo a autoridade fiscal na coleta de pagamentos contingentes à renda, programas governamentais de financiamento estudantil conseguem conciliar sustentabilidade fiscal com acesso equitativo ao ensino superior.

O sistema norte-americano, sendo uma complexa teia de empréstimos e bolsas, tem poucas características positivas a serem aproveitadas. Pesquisas sugerem que a complexidade do sistema norte-americano dificulta acesso ao financiamento federal. ${ }^{7}$ Simplicidade é importante, mas esta é uma característica que nem o sistema norte-americano nem o brasileiro apresentam. Ademais, quem não consegue uma bolsa e não tem condiçôes de pagar por um curso superior nos Estados Unidos não dispóe de alternativas de crédito educativo que efetivamente proteja contra dificuldades de pagamento causadas por intempéries futuras no mercado de trabalho (desemprego e subemprego, por exemplo). As modalidades-padrão de crédito educativo não são contingentes à renda. As que são, exigem recadastramento anual e equiparam a dívida eventualmente perdoada (o que acontece se há débitos pendentes após 20 ou 25 anos, a depender do plano) à renda pessoal tributável. Portanto, quem não obtém meios para pagar nunca chega a ver sua dívida estudantil perdoada, na melhor das hipóteses ela é substituída por uma dívida tributária.

Como aspecto positivo, o sistema norte-americano é bem integrado; um ativo que falta ao sistema brasileiro. Embora tanto o Prouni quanto o Fies sejam programas federais, há sobreposição entre eles. Integrá-los traria ganhos de eficiência, que se amplificariam se o Fies viesse a se tornar, efetivamente, um ECR. Para que isso ocorra, seria necessário retirar a exigência de pagamento mínimo, que compromete o componente de proteção social desejável em um ECR, e envolver a Receita Federal na coleta dos reembolsos, automatizando o desconto em folha e expandindo a cobrança para outras fontes de renda. Deve-se evitar, contudo, juro real zero, pois implica elevados custos ao governo e beneficia até quem futuramente vier a ter alto padrão de renda, quando o ECR já protege os mais pobres. Com um ECR a pleno funcionamento, Prouni e Fies poderiam ser fundidos, já que egressos com salários baixos ao longo da vida eventualmente têm parte ou mesmo a totalidade de suas dívidas perdoadas, casos em que o ECR funciona como uma bolsa concedida a posteriori. Enquanto coexistissem, a integração permitiria um melhor direcionamento de estudantes de mais baixa renda ao Prouni e os demais ao Fies, focalizando melhor a ajuda federal.

Pode-se dizer, com razão, que as realidades australiana, brasileira e americana são muito diferentes. Essas diferenças dificultariam replicar no Brasil muitas das políticas públicas bem-sucedidas nesses países. No entanto, a integração das políticas federais de financiamento estudantil e a implementação de um ECR eficaz e sustentável são factíveis para o Brasil. As principais reformas legislativas para transformar o Fies em um ECR já foram feitas, restando ajustes finos no desenho do programa e o envolvimento da Receita Federal na coleta dos pagamentos. Um amplo e bem desenhado ECR poderia ajudar, ainda, a reposicionar o recorrente debate acerca da manutenção ou não da gratuidade em IES públicas, pois coloca em pauta uma alternativa que concilia gratuidade durante os estudos com contribuição financeira de acordo com a capacidade de pagamento dos egressos do sistema de ensino. 


\section{APÊNDICE}

TABELA A. 1

Principais características dos sistemas de financiamento estudantil do Brasil, da Austrália e dos Estados Unidos

\begin{tabular}{|c|c|c|c|}
\hline & Brasil & Austrália & Estados Unidos \\
\hline Modalidades de financiamento & $\begin{array}{l}\text { Gratuidade para todos matriculados em } \\
\text { IES públicas. Bolsas e empréstimos em } \\
\text { IES privadas, somente para } \\
\text { alunos elegíveis. }\end{array}$ & Empréstimos estudantis. & $\begin{array}{l}\text { Sistema integrado (e complexo) de } \\
\text { bolsas e empréstimos. Gratuidade em } \\
\text { (poucas) IES públicas, somente para } \\
\text { alunos elegíveis. }\end{array}$ \\
\hline Percentual de matrículas em IES públicas & $25 \%$ & $82 \%$ & $76 \%$ \\
\hline $\begin{array}{l}\text { IES elegíveis para empréstimos } \\
\text { estudantis }\end{array}$ & $\begin{array}{l}\text { Somente privadas (até } 2017 \text { ). Privadas } \\
\text { e autarquias estaduais e municipais (a } \\
\text { partir de 2018). }\end{array}$ & Públicas e privadas. & Públicas e privadas. \\
\hline Modalidade de amortização' & $\begin{array}{l}\text { EAT (até 2017) } \\
\text { ECR (a partir de 2018) }\end{array}$ & ECR & Padrão: EAT; ECR em casos especiais. \\
\hline Prazo de carência & $\begin{array}{l}\text { Dezoito meses após conclusão do curso } \\
\text { (até 2017) } \\
\text { Não há carência (a partir de 2018) }\end{array}$ & $\begin{array}{l}\text { Não há. Amortização automática, } \\
\text { ocorrendo sempre que a renda supera } \\
\text { limite de isenção. }\end{array}$ & Seis meses após conclusão do curso. \\
\hline Prazo máximo de amortização & $\begin{array}{l}\text { Três vezes a duração do curso + } 12 \\
\text { meses (até 2017) } \\
\text { Não definido (a partir de 2018) }\end{array}$ & Variável & Padrão: 10 anos; pode chegar a 25. \\
\hline Valor máximo de financiamento & Até $\mathrm{R} \$ 42$ mil por semestre & Variável & Variável \\
\hline Taxa nominal de juros & $\begin{array}{l}\text { 6,5\% a.a. (até } 2017 \text { ) } \\
\text { Variável. Principal modalidade atualiza } \\
\text { saldo devedor pela inflação (a partir de } \\
2018 \text { ) }\end{array}$ & Saldo devedor atualizado pela inflação & $4,45 \%$ a.a. \\
\hline Taxa de inadimplência² & $40,7 \%$ & $18 \%$ & $14 \%$ a $20 \%$ \\
\hline $\begin{array}{l}\text { Critérios para a concessão de emprés- } \\
\text { timo estudantil }\end{array}$ & Renda familiar e desempenho no Enem & Não há & $\begin{array}{l}\text { Critério de renda para a modalidade } \\
\text { subsidiada e para o } \mathrm{ECR}^{3}\end{array}$ \\
\hline
\end{tabular}

Elaboração dos autores.

Notas: ${ }^{1}$ EAT: empréstimos com amortizações a termo; ECR: empréstimos com amortizações contingentes à renda futura.

2 Dados reportados em relatórios oficiais. No caso australiano, o dado não se refere à taxa de inadimplência, mas sim à proporção de dívida que não será paga, também chamada de dívida incerta. No caso norte-americano, considera-se inadimplência atrasos superiores a 270 dias. No caso brasileiro, atrasos superiores a noventa dias (baixa probabilidade de recuperação, segundo o Banco Central). Aplicando-se ao Brasil a mesma definição utilizada nos Estados Unidos, a taxa de inadimplência seria próxima a 30\%.

${ }^{3}$ O financiamento estudantil padrão nos Estados Unidos pode ser subsidiado ou não subsidiado. No subsidiado, alunos com comprovada necessidade financeira não pagam os juros do empréstimo enquanto matriculados. Na modalidade não subsidiada, incidem juros mesmo durante a fase de utilização (matrícula). Quem enfrenta dificuldades para pagar sua dívida estudantil pode solicitar migração para o plano contingente à renda. 


\section{ALGUNS COMENTÁRIOS A RESPEITO DAS REFORMAS RECENTES NO FIES E OS DESAFIOS ATUAIS}

Manoel Pires ${ }^{1}$

\section{INTRODUÇÃO}

O Fundo de Financiamento ao Estudante do Ensino Superior (Fies) é o principal programa de financiamento de ensino superior do Brasil. Para parte significativa da população, o crédito estudantil é a segunda decisão de consumo mais importante, perdendo apenas para a aquisição de um imóvel.

Do ponto de vista teórico, a racionalidade para intervenção estatal nesse mercado é muito clara. A expansão da escolaridade média da população é um fator importante do desenvolvimento econômico, incentiva a maior produtividade da mão de obra, a inovação, a redução da criminalidade etc. As externalidades positivas são incontroversas. Além disso, esse é um mercado em que o crédito é extremamente escasso, pois a maior parte dos estudantes não possui condições de oferecer garantias adequadas e a renda futura é muito incerta. Por essas razóes, o sistema de crédito público subsidiado é a norma nesse segmento.

Do ponto de vista prático, a implementação desses programas é um enorme desafio. Os subsídios são elevados e a taxa de inadimplência bastante significativa. Em vários casos, há perdão para dívidas após certo prazo de pagamento. Mesmo nas melhores experiências e nos modelos mais modernos o custo fiscal é substancial.

O governo Obama, por exemplo, implementou uma grande reforma no sistema de crédito estudantil adotando o modelo income based repayment (IBR), no qual o estudante paga o financiamento a partir de uma fração do seu salário depois de formado e empregado. Mesmo com taxas de juros muito baixas, as dívidas se acumularam e as taxas de inadimplência também cresceram em função dos baixos salários praticados no mercado de trabalho americano no pós-crise.

No Brasil, houve notável expansão do programa entre 2011 e 2014, quando o número de novos contratos por ano saltou de 150 mil para mais de 700 mil. Naquele momento existiam quase 2 milhôes de contratos ativos. O crescimento se deu em função de condiçóes financeiras que se tornaram bastante favoráveis a partir de 2010 e da maior disponibilidade de vagas oferecidas ano após ano. Pelo lado da demanda por educação, o aumento do emprego criou expectativas nos estudantes de que a elevação da escolaridade elevaria a empregabilidade e os salários. Mas em função desse crescimento e do elevado custo fiscal, foi necessário rever o tamanho e o modelo do programa. ${ }^{2}$ Por conta disso, o governo federal, em 2015, revisou algumas normas.

\footnotetext{
1. Pesquisador na Faculdade de Economia, Administração, Contabilidade e Gestão de Políticas Públicas (FACE) da Universidade de Brasília (UnB) e coordenador do Observatório de Política Fiscal do Instituto Brasileiro de Economia da Fundação Getulio Vargas (IBRE/FGV). E-mail: <manoel.pires@fgv.br>.

2. Além de condições financeiras mais favoráveis, o que aumentava o subsídio por aluno, uma série de alterações permitiram que o fundo garantidor aumentasse sua alavancagem, o que viabilizou a expansão do número de vagas com maior concentração do risco de crédito na União. Ao longo dessas mudanças, o custo fiscal do programa aumentou consideravelmente. Em 2011, a estimativa é que tenha custado R\$1,9 bilhão, enquanto que, em 2017, já custava R\$ 30 bilhões. Atualmente, o passivo fiscal do programa - referentes a dívidas em atraso - gira em torno de R\$20 bilhões. Ver BRASIL. Ministério da Fazenda. Diagnóstico Fies. Brasília: MF, 2017. Disponível em: <https://goo.gl/Hntqh9>. Acesso em: 26 nov. 2018.
} 
A revisão do Fies foi estudada por um grupo de trabalhado criado para propor ajustes em várias políticas públicas, o Grupo de Trabalho para Acompanhamento do Gasto (GTAG) que desenvolveu mudanças para o Fies, o seguro defeso, o Benefício de Prestação Continuada (BPC), o auxílio doença, dentre outros programas.

No trabalho desenvolvido para o Fies é importante destacar o contexto político do país naquele momento, bem como o contexto do próprio programa. Em 2015, o país passava por uma crise política e o Congresso havia lançado a pauta bomba que representava um conjunto de assuntos de elevado impacto fiscal e desgaste do governo perante a sociedade. O Congresso Nacional ameaçava derrubar vários vetos presidenciais que até então nunca haviam sido apreciados. Em função desses acontecimentos era recomendável que se evitasse soluçóes técnicas que passassem por mudanças legais.

O programa, por sua vez, passava por uma crise. No final de 2014, o Ministério da Educação alterou a forma de repasse para as instituiçóes de ensino superior (IES), o que resultou em atraso dos desembolsos. Como as IES náo estavam mais recebendo os pagamentos conforme planejado, elas começaram a repassar alguns custos para os alunos, cancelaram algumas matrículas e, ao mesmo tempo, acionaram o Ministério da Educação (MEC) na justiça.

A insatisfação social foi grande e diante das dificuldades financeiras do governo, houve receios de que o programa sofresse um grande abalo. Dessa forma, a prioridade do GTAG era construir uma soluçáo técnica que não utilizasse um caminho legislativo e que viabilizasse financeiramente o programa para ser utilizado já no segundo semestre de 2015 .

\section{AS PRINCIPAIS MUDANÇAS NA REFORMA DE 2015}

Os estudos iniciais recomendavam a adoção dos modelos em que o pagamento do financiamento é contingente à renda do devedor. Esse modelo, com várias nuances, é utilizado nos Estados Unidos, Reino Unido e Austrália e o estudante amortiza a dívida a partir de um percentual do seu salário depois de formado e empregado. Algumas questôes críticas impediram que se seguisse aquele caminho na época. A primeira era que a experiência brasileira com financiamentos cuja amortizaçáo ocorria de forma contingente à renda náo era auspiciosa. Nos anos 1960, por exemplo, os contratos de financiamento imobiliário possuíam essa característica o que levou os mutuários a subdeclararem suas rendas. Com isso, os financiamentos não eram quitados. A solução foi criar o Fundo de Compensação de Variaçôes Salariais (FCVS) em que a União assumiu o compromisso de honrar esses contratos. A conta é paga pelo Tesouro até hoje.

Essa crítica poderia ser relativizada se fosse possível integrar as informaçóes de renda com a Receita Federal. Infelizmente, não foi possível, construir essa solução a tempo. A experiência sugere que é necessário bastante tempo para que os sistemas de informação do setor público sejam aperfeiçoados. O E-social, por exemplo, levou muitos anos para se tornar operacional. De todo o modo, é importante avançar na integração dos sistemas de tributação para aperfeiçoar o desenho das políticas públicas.

A reforma foi feita, portanto, combinando o que era possível absorver da experiência internacional do funcionamento prático do programa e a realidade brasileira do momento.

Dentre as mudanças mais importantes estão o realinhamento dos critérios de renda, o fim do financiamento integral, o aumento das coparticipaçóes e da taxa de juros e a reduçáo do número de vagas. Buscava-se dessa maneira contemplar três objetivos: reduzir os custos do programa, realinhar os incentivos e melhorar a governança. Estimava-se que o subsídio por aluno cairia em 30\% no modelo novo.

Antes da reforma, $80 \%$ dos contratos eram de financiamento integral. Entre os problemas que isso criava estava o fato de que a dívida se tornava muito grande para ser paga e que muitos estudantes entendiam que 
haviam ganho uma bolsa e que não tinham que pagar um financiamento estudantil. Essa modalidade de financiamento foi encerrada.

O realinhamento das condiçóes financeiras levou a uma redefinição da taxa de juros pela remuneração da poupança e a definição de limites de comprometimento de renda com base na renda familiar bruta per capita. Os limites de comprometimento de renda foram definidos de forma progressiva para que as famílias mais ricas pudessem pagar seus financiamentos de forma mais célere enquanto para as famílias mais pobres o financiamento seria mais prolongado e o subsídio resultante seria maior. Essa foi, naquele momento, a forma possível de definir o pagamento como função da renda.

TABELA 1

Modelo de coparticipação

\begin{tabular}{lcccc}
\hline $\begin{array}{l}\text { Renda familiar bruta per capita } \\
\text { (RFB-PC) }\end{array}$ & $\begin{array}{c}\text { Comprometimento da RFB-PC } \\
\text { (com encagos educacionais - \%) }\end{array}$ & $\begin{array}{c}\text { Cofinanciamento } \\
\text { (parte a ser paga pelo aluno da } \\
\text { faixa superior - R\$) }\end{array}$ & $\begin{array}{c}\text { Financiamento curso médio } \\
(\%)^{1}\end{array}$ & Financiamento medicina (\%) \\
\hline Até 0,5 SM & 15 & 59,10 & 93,8 & 98,5 \\
$>0,5$ SM a 1 SM & 21 & 165,48 & 82,7 & 95,8 \\
$>1$ SM a 1,5 SM & 27 & 319,14 & 66,6 & 91,9 \\
$>1,5$ SM a 2,0 SM & 32 & 504,32 & 47,2 & 87,2 \\
$>$ 2,0 SM a 2,5 SM & 38 & 748,60 & 21,6 & 81,0 \\
\hline
\end{tabular}

Fonte: Pires (2015). ${ }^{3}$

Nota: ${ }^{1}$ Considera valores de 2014; custo médio de mensalidade em R\$955,00.

Um resultado dessa redefinição foi que os subsídios por faixa de renda se tornaram mais uniformes. Para verificar isso, o gráfico 1 apresenta o subsídio teórico de um contrato por faixa de renda. Ele é calculado como a diferença do fluxo de caixa nas condiçôes financeiras do programa em relaçáo a um fluxo de caixa cujo contrato é remunerado pela taxa Selic.

\section{GRÁFICO 1}

Subsídio do Fies por faixa de comprometimento de renda

$1 \mathrm{~A}$ - Modelo vigente até 2014

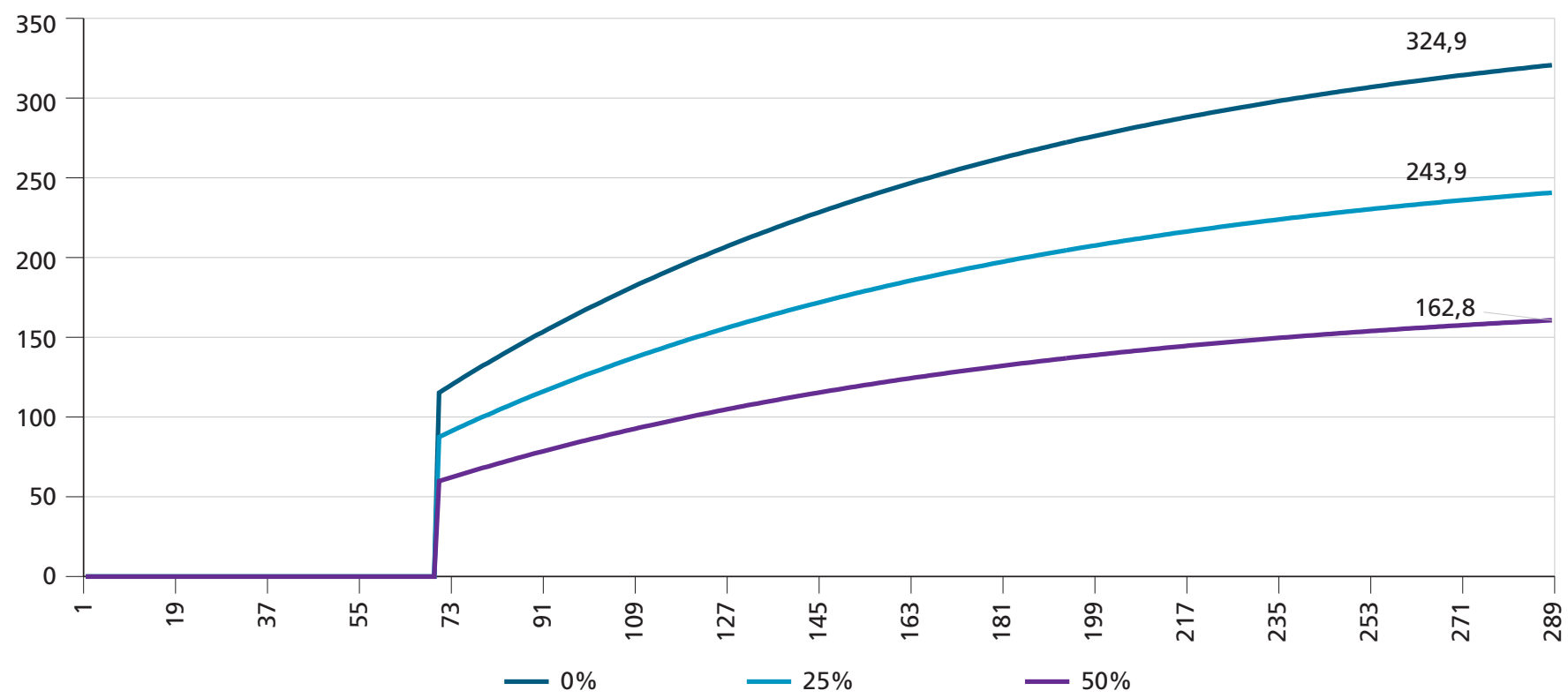


1B - Modelo vigente entre 2015 e 2017

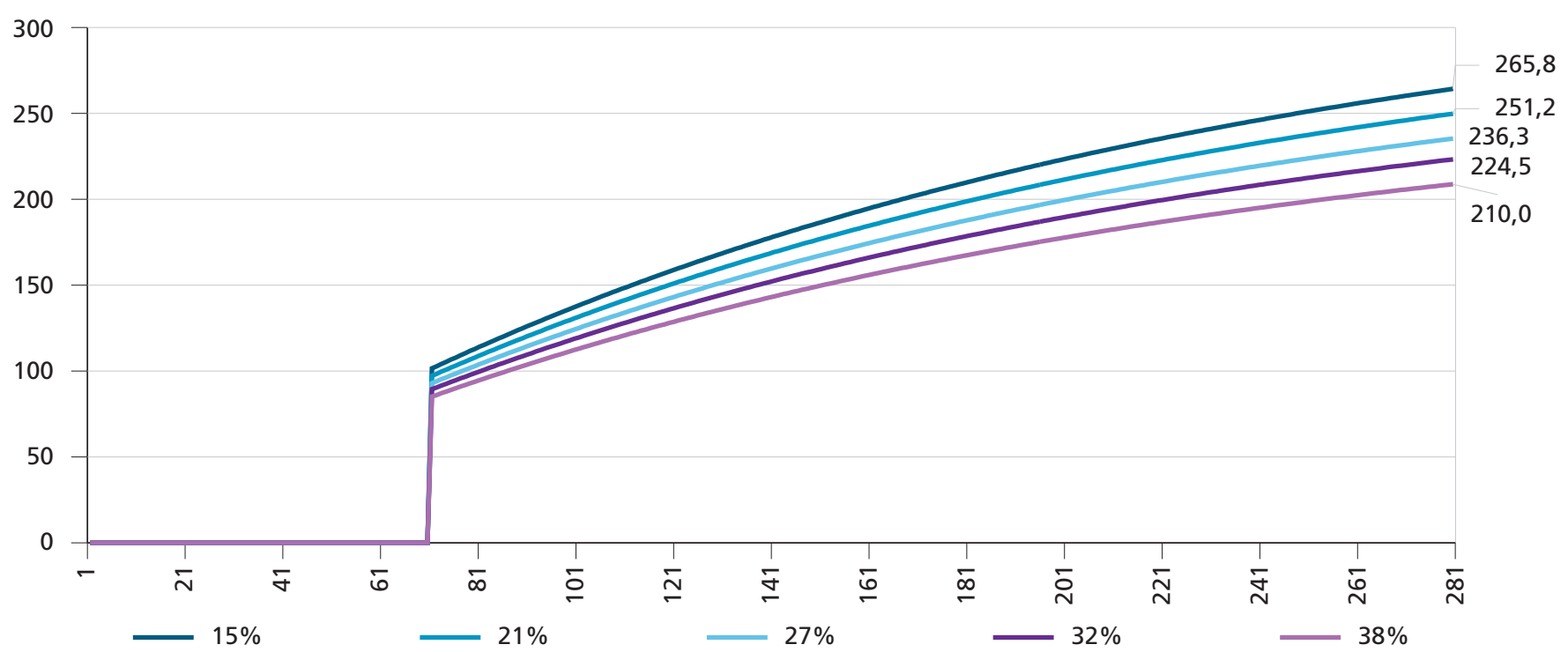

Fonte: Pires (2015).

No modelo vigente até 2014, é possível verificar que as três faixas de renda utilizadas para definir o contrato implicavam subsídios muito díspares entre cada uma. Como o subsídio presente no financiamento integral era muito superior aos demais, o incentivo era para que os estudantes subdeclarassem sua renda para entrar na modalidade mais favorecida.

Ao aumentar o número de faixas e reduzir os subsídios, esse incentivo foi bastante diminuído. Ainda assim, o programa continuou progressivo pois o subsídio da parcela final do contrato é $26 \%$ maior para os mais pobres em relação à maior parcela de comprometimento.

Além de revisar as condições financeiras do programa, uma outra forma de reduzir o custo é diminuir o número de contratos novos. Isso também foi feito em 2015 quando foram ofertadas 323 mil novas vagas, das quais 287 mil foram preenchidas. Isso representou menos de metade das vagas ofertadas no ano anterior. Na prática, o programa estava voltando ao tamanho que ele tinha em 2012. Para a frente, projetava-se um crescimento estável das vagas. A ideia era que se estabelecesse um planejamento de longo prazo para a abertura de novas vagas que reduzisse a incerteza do programa pelo lado da oferta.

\section{GRÁFICO 2}

Novas matrículas do Fies (2011-2024)

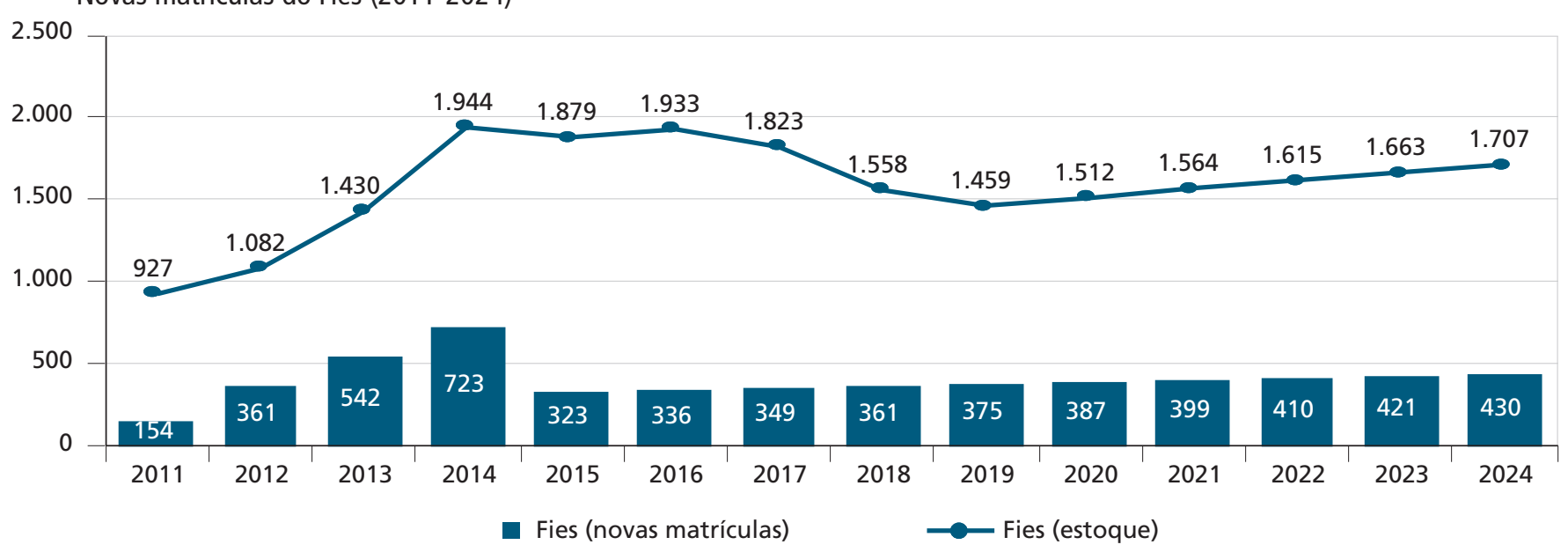




\section{A REFORMA DE 2017}

Em 2017, o governo federal propôs uma série de mudanças no Fies por intermédio da Medida Provisória n⿳o 785 . Dentre as principais mudanças está a possibilidade de que a amortização possa ser consignada em folha de pagamento, aproximando o programa ainda mais dos modelos contingentes à renda. As instituiçóes de ensino superior deverão elevar suas contribuições no Fundo Garantidor reduzindo a concentração de risco de crédito para a União. Isso na prática tende a elevar o custo da mensalidade para o aluno.

Uma outra mudança está na indexação da taxa de juros à inflação. Isso é comum em outros países e evita que a taxa real se torne negativa. ${ }^{4}$ Também foi criada uma modalidade do Fies a ser operada por bancos públicos e privados. Essa nova modalidade não deve ser responsável pela elevação substancial das matrículas já que por conta das características desse programa a iniciativa privada não costuma ter atuação relevante. De fato, o levantamento mais recente indicou que apenas 265 contratos foram fechados das 105 mil vagas disponibilizadas.

O Tesouro Nacional passou a explicitar as despesas com o Fies nas estatísticas fiscais. Esse foi um passo importante para aumentar a transparência do custo do programa. Por fim, foi criado um comitê interministerial para fortalecer a governança do programa. Essa é uma área importante para avanços, pois uma das razóes para o crescimento do custo fiscal do programa foi a falta de transparência do programa e a imperfeição dos indicadores de monitoramento. Mas a experiência prática com esses comitês no governo federal cria dúvidas sobre o sucesso dessa iniciativa.

\section{ALGUNS DESAFIOS}

A Medida Provisória no 785 , convertida na Lei n⿳o 13.530/2017, avançou na agenda introduzida pela reforma de 2015, revisando algumas condiçóes financeiras e a sustentabilidade de longo prazo do programa. Nesse sentido, em vários aspectos ela deu continuidade a esse conjunto de iniciativas.

$\mathrm{O}$ aspecto mais emergencial está em resolver o problema da inadimplência do Fies que gira em torno de $50 \%$, com risco fiscal aproximado de $\mathrm{R} \$ 20$ bilhóes. Atualmente, não há mecanismo de renegociação de dívida estudantil. Um estudante que possui parcelas atrasadas deve pagar toda a dívida à vista para regularizar sua situação. Um sistema como esse é um convite a inadimplência. Esses mecanismos são bastante comuns em outros países e deveria ser instituído no sistema brasileiro. A nova legislação possibilitou a renegociação que recentemente foi regulamentada pelo MEC. É importante acompanhar se esse processo vai ser bem sucedido. .

Uma outra iniciativa importante seria criar incentivos financeiros para pré-pagamento e estabelecer mecanismos progressivos de pagamento uma vez que os salários são mais baixos nas fases iniciais da carreira. Isso reduziria o risco de inadimplência e permitiria que os pagamentos fossem acelerados em momentos em que o mercado de trabalho estivesse mais favorável. Dessa forma, o governo recuperaria seus recursos de forma mais célere e em maior montante.

Apesar da explicitação das despesas nas estatísticas ser um passo importante para a transparência do programa, o efeito sobre a melhora da governança é muito pequeno. Isso ocorre porque há grande defasagem temporal entre a definição da política e o seu custo efetivo que só se materializa muito tempo depois. Nesse sentido, é importante que o orçamento traga informaçôes sobre o custo do programa no momento em que a política está sendo discutida entre o governo e o Congresso Nacional. Para isso, é necessário que a peça orçamentária apresente

4. Na prática, a mudança da taxa de caderneta de poupança para a taxa de inflação aumentou o subsídio. Como as taxas de juros são elevadas no Brasil, essa mudança pode implicar elevado subsídio. De todo o modo, evita situações que já ocorreram no passado em que a taxa real se tornou negativa. Se 0 financiamento estudantil efetivamente vier a caminhar para um financiamento contingente à renda, o juro real pode ser positivo, pois já haverá um subsídio garantido aos mais pobres, se o programa for desenhado com um perdão da dívida remanescente quando da aposentadoria ou morte do devedor. 
um capítulo sobre crédito público que traga informaçóes sobre os subsídios esperados, custo futuro total desses programas e demais custos financeiros no momento da definição das políticas.

As novas matrículas com financiamento do Fies estão em forte queda. No primeiro semestre deste ano apenas 54\% das 82 mil vagas foram preenchidas. Assim, em 2018 o número de novas matrículas deverá ser inferior a 100 mil de modo que o programa tem retrocedido na sua contribuição para a expansão da educação superior no Brasil. Isso é fruto da elevada taxa de desemprego que retira a confiança dos jovens no futuro fazendo com que adiem decisóes importantes como essa ou que considerem que a educação não é atraente, dado que imaginam que continuarão desempregados. Isso só vai se resolver com a melhora da economia. Mas do ponto de vista de desenho de política, é importante que se evite a rotina de mudanças muito drásticas no programa para que a desconfiança no Fies não aumente ainda mais. Nesse sentido, o ideal é que a adoção de modelos contingentes à renda ocorra de forma integral e não mais por parcelas. 


\title{
A REESTRUTURAÇÃO DO FIES'
}

\author{
Mansueto Facundo de Almeida Júnior² \\ Alexandre Manoel Angelo da Silva ${ }^{3}$ \\ Aumara Feu ${ }^{4}$ \\ Jossifram Almeida Soares ${ }^{5}$ \\ Rodrigo Leandro de Moura ${ }^{6}$ \\ Luciano de Castro Pereira ${ }^{7}$
}

\section{INTRODUÇÃO}

O programa de crédito estudantil do governo federal para ajudar alunos carentes a ingressarem no ensino superior foi criado em $1976 .{ }^{8}$ Este programa entrou em crise em $1991,{ }^{9}$ em decorrência da inexistência de recursos para conceder novos financiamentos, da ausência de mecanismos eficazes de cobrança do pagamento dos empréstimos e das concessóes acima de sua capacidade de crédito, tendo funcionado de maneira precária desde então, até ser descontinuado em 1997. ${ }^{10}$

Em 1999, o governo federal voltou a conceder crédito estudantil por meio do Fundo de Financiamento Estudantil (Fies), instituído pela Medida Provisória (MP) no 1.827, de 27 de maio de 1999. Posteriormente, essa MP foi transformada na Lei no 10.260 , de 12 de julho de 2001, que destina a concessão de financiamento a estudantes regularmente matriculados em cursos superiores não gratuitos e com avaliação positiva nos processos conduzidos pelo Ministério da Educação (MEC).

Entre 1999 e 2010, o fluxo anual médio do Fies era de aproximadamente 50 mil novos alunos, e o total de financiamentos ativos (estoque), em 2010, era de 200 mil alunos. Com a implantação, em 2010, do Fundo de Garantia de Operações de Crédito Educativo (FGEDUC) - fundo que concede garantia de quase todo o valor financiado e tem a União como única cotista -, o Fies cresceu vigorosamente, atingindo fluxo anual de 733 mil novos financiamentos em 2014, caindo para um patamar anual de contratação inferior a 300 mil contratos no triênio 2015-2017.

Em 2017, o estoque de financiamentos ativos do programa era de aproximadamente 2 milhóes de contratos, cerca de dez vezes maior que o existente em 2010, com o ônus fiscal ${ }^{11}$ do programa passando de R $\$ 1,9$ bilhão, em 2011, para R \$29,1 bilhóes, em 2017.

1. Publicação institucional resultante de trabalho desenvolvido no âmbito do grupo de trabalho informal instituído pelo Ministério da Educação (MEC) e pelo Ministério da Fazenda (MF) para reestruturação do Fundo de Financiamento Estudantil (Fies).

2. Secretário do Tesouro Nacional do MF.

3. Secretário de acompanhamento fiscal, energia e loteria do MF.

4. Coordenadora-geral de estudos fiscais da Secretaria de Acompanhamento Fiscal, Energia e Loteria do MF.

5. Coordenador de estudos fiscais da Secretaria de Acompanhamento Fiscal, Energia e Loteria do MF.

6. Chefe de divisão da Coordenação-Geral de Estudos Fiscais da Secretaria de Acompanhamento Fiscal, Energia e Loteria do MF.

7. Analista da Coordenação-Geral de Estudos Fiscais da Secretaria de Acompanhamento Fiscal, Energia e Loteria do MF.

8. Instituído com base na Exposição de Motivos no 393, de 18 de agosto de 1975, do MEC (aprovada pela Presidência da República) e na Resolução no 356, do Banco Central do Brasil (BCB), de 12 de janeiro de 1976.

9. 0 programa foi institucionalizado por meio da Lei n 8.436, de 25 de junho de 1992.

10. "O programa financiou vagas pela última vez em 1997, ocasião em que atendeu 58.709 estudantes (...). As avaliações feitas indicam que o Programa foi desativado no início da década de 2000 (...). Em decorrência, foram atendidos os alunos que já tinham contraído os empréstimos em anos anteriores". BRASIL. Ministério da Educação. Desenvolvimento, aprimoramento e consolidação de uma educação nacional de qualidade. Brasília: MEC, 2013.

11. Decorrente dos seguintes dispêndios: despesas financeiras, aportes da União ao Fundo de Garantia de Operações de Crédito Educativo (FGEDUC), despesas administrativas e subsídios creditícios. 
Este texto descreve resumidamente a reestruturação do Fies ocorrida no biênio 2016-2017 com o objetivo de evitar nova descontinuação na concessão de crédito estudantil aos alunos carentes e de tornar tal concessão sustentável. Inicialmente, apresenta-se o diagnóstico do programa e, posteriormente, as principais soluçóes implementadas pelo Novo Fies. ${ }^{12}$

\section{DIAGNÓSTICO DO MODELO VIGENTE EM 2017}

Foram observadas ${ }^{13}$ três causas principais da insustentabilidade fiscal do programa: $i$ ) má alocação do risco de crédito; ii) falta de previsibilidade do seu custo; e iii) governança precária.

A primeira causa da insustentabilidade do programa foi a alocação inapropriada do risco de crédito, com elevada concentração na União, pois a contribuição das instituições de ensino superior (IES) para o FGEDUC era baixa (inferior a $10 \%$ do financiamento concedido pelo Fies) e não variava com a performance de suas carteiras de alunos financiados. Com isso, inadimplências superiores a $10 \%$ se transformavam em passivo para a União, o que estimulava as IES a ofertarem quantidade excessiva de cursos, independentemente da qualidade e da demanda do mercado de trabalho.

Ademais, os alunos incorriam em risco moral, em decorrência da pouca clareza sobre a natureza e as condiçôes do crédito contratado, levando-os, muitas vezes, a confundir o financiamento com bolsa de estudo, o que reduzia a percepção sobre reajustes de mensalidades e elevava a inadimplência.

Ainda quanto ao risco, destaca-se a subestimação da inadimplência considerada pelo FGEDUC, de 10\%, ${ }^{14}$ nível muito baixo comparativamente à inadimplência atual de 40,7\% da carteira Fies (tabela 1) nos contratos em fase de amortização desde 2010.

\section{TABELA 1}

Contratos de inadimplência por dias de atraso

\begin{tabular}{lccc}
\hline Risco BCB & Dias de Atraso & Contratos inadimplentes em amortização & $\begin{array}{c}\text { Percentual de inadimplentes frente ao total de } \\
\text { contratos em amortização }\end{array}$ \\
\hline A & 1 a 15 & 40.368 & 6,6 \\
B & 16 a 30 & 57.836 & 9,4 \\
C & 31 a 60 & 17.937 & 2,9 \\
D & 61 a 90 & 12.561 & 2,1 \\
E $^{1}$ & 91 a 120 & 12.333 & 2,0 \\
$F^{1}$ & 121 a 150 & 5.273 & 0,9 \\
$G^{1}$ & 151 a 180 & 5.564 & 40,7 \\
$H^{1}$ & Superior a 180 & 226.315 & 0,9 \\
\hline & Total & 378.187 & 37,0
\end{tabular}

Fonte: FNDE, março de 2018. Dados do BB e Caixa para contratos a partir de 2010.

Nota: ${ }^{1}$ Contratos com inadimplência de mais de 90 dias apresentam baixa probabilidade de recuperação, segundo o Banco Central.

12. Por meio do Acórdão n 3.001/2016, o Tribunal de Contas da União (TCU) determinou ao MEC, ao Fundo Nacional de Desenvolvimento da Educação (FNDE) e ao Ministério do Planejamento, Desenvolvimento e Gestão (MP) que, dentre outras atribuições, elaborassem um plano de trabalho visando à sustentabilidade do Fies. Posteriormente, por meio do Acórdão n 539/2017, o TCU incluiu o MF na relação de órgãos e entidades responsáveis pelo cumprimento do referido plano de trabalho.

13. Para mais informações, ver BRASIL. Ministério da Fazenda. Diagnóstico Fies. Brasília: MF, 2017. Disponível em: <https://goo.gl/h8U63m>. Acesso em: 26 nov. 2018.

14. No desenho do fundo que permite alavancagem de dez vezes, ou na regra de stop loss de $10 \%$. 
A segunda causa de insustentabilidade do programa era a falta de previsibilidade do custo Fies, que diminuía a previsibilidade orçamentária do programa, piorando o risco fiscal e a governança. O subsídio creditício, decorrente especialmente do diferencial de taxa de juros, náo era amplamente divulgado, e a inadimplência não era adequadamente contabilizada na despesa primária do governo central, algo que foi corrigido apenas em 2016.

Com relação à governança inadequada, uma fragilidade importante era a ausência de planejamento relacionada à oferta de vagas, que crescia desconsiderando os riscos fiscais, o comprometimento do orçamento e as outras políticas com as quais o programa eventualmente possuía sobreposição.

\section{PRINCIPAIS ALTERAÇÕES PROMOVIDAS PELO NOVO FIES}

Foram mapeados três grandes desafios para o novo programa: alinhar os incentivos dos agentes, garantir previsibilidade e perenidade ao programa por meio da reduçáo do seu custo fiscal e aprimorar sua governança.

A reestruturação do Fies, ${ }^{15}$ consubstanciada na MP no 785/2017 (convertida na Lei no 13.530 , de 7 de dezembro de 2017), passou a ser aplicada a partir do processo seletivo do $1^{\circ}$ semestre de 2018 , náo afetando os contratos anteriores.

O Novo Fies prevê três modalidades de crédito educativo para acesso ao ensino superior. A primeira, resultante da reestruturação do Fies existente até 2017, tem fundo garantidor e é direcionada às famílias com renda per capita de até três salários mínimos - limite que não foi alterado em relação ao Fies anterior -, permitindo que estudantes carentes tenham acesso ao programa. As outras modalidades, inéditas, abrangem faixas maiores de renda, não têm fundo garantidor e o risco de crédito é alocado nas instituiçóes financeiras.

Neste texto, focamos na restruturação da primeira modalidade, direcionada às famílias de menor renda e baseada em três medidas estruturantes: i) redesenho do pagamento do financiamento, vinculando-o à renda futura do estudante; ii) instituição de novo fundo garantidor, que desconcentra o risco de crédito da União; e iii) criação do Comitê Gestor do Fies, que aprimora a governança do programa. Além dessas medidas, destaca-se a fixaçáo da taxa real de juros zero, dando maior previsibilidade ao subsídio creditício e garantindo crédito público com menor taxa de juros. As principais alteraçóes estão ilustradas no quadro 1 e descritas a seguir.

\section{QUADRO 1}

Principais mudanças na reestruturação do Fies

\begin{tabular}{|c|c|c|}
\hline & Modelo antigo & Modelo novo \\
\hline Taxa de juros & Nominal fixa & Real zero \\
\hline Fundo garantidor & $\begin{array}{l}\text { Considera inadimplência subestimada e fixa, concentrando risco na } \\
\text { União }\end{array}$ & $\begin{array}{l}\text { Considera inadimplência verificada e variável por IES, elevando a sua } \\
\text { participação no risco }\end{array}$ \\
\hline $\begin{array}{l}\text { Reajuste das } \\
\text { mensalidades }\end{array}$ & Não tinha limitador ao longo do contrato do aluno & $\begin{array}{l}\text { É estabelecido pela IES no momento em que o financiamento é } \\
\text { firmado pelo aluno }\end{array}$ \\
\hline Governança & Concentrada nos órgãos públicos setoriais & É compartilhada entre diversos órgãos da administração pública \\
\hline Pagamento & Em três vezes o período do curso, com carência de dezoito meses & $\begin{array}{l}\text { Prazo variável, pois a parcela a ser paga é um percentual da renda } \\
\text { do egresso do ensino superior, a ser retida na fonte de pagamento } \\
\text { pelo empregador }\end{array}$ \\
\hline
\end{tabular}

Elaboração dos autores. 
O redesenho do pagamento do financiamento tem início na fase de utilização, quando o aluno está cursando o ensino superior. Nessa fase, a definição da coparticipação (parcela paga pelo aluno durante o curso) passou a incluir componente que depende do valor do curso, ampliando a sensibilidade ao preço e ensejando a concorrência entre as IES, com reflexo positivo sobre a modicidade dos encargos educacionais.

Ademais, o aluno pagará a coparticipação diretamente ao agente financeiro do programa, que a repassará às mantenedoras caso o pagamento seja realmente efetivado, diferentemente do modelo antigo em que se pagava diretamente às IES. Esta medida impede que as IES concedam desconto integral da coparticipaçáo, eventualmente compensado por elevação no ticket médio (valor da mensalidade do curso), além de deixar claro para o aluno que o Fies é um financiamento, e não uma bolsa.

Na segunda fase, após a conclusão do curso, eliminou-se a carência. A ideia foi suavizar o valor dispendido pelo aluno ao longo de todas as fases do financiamento, sem interrupçóes no pagamento e sem sobressaltos no valor. A experiência no mercado de crédito mostra que esta suavização nos pagamentos diminui a inadimplência. Ademais, há coerência em não interromper o compromisso do aluno, já que, ao longo do curso, ele pagava a coparticipação.

A amortização do financiamento passou a ser realizada por meio de pagamento vinculado à renda futura do estudante. Este modelo, conhecido na literatura internacional por income contingent loan (ICL), ${ }^{16}$ tem sido utilizado em diversos países, sendo exitoso em reduzir a inadimplência, por respeitar a capacidade de pagamento do aluno e permitir o desconto do valor devido na folha de pagamento. Esta forma de pagamento será implementada utilizando o Sistema de Escrituração Digital das Obrigaçôes Fiscais, Previdenciárias e Trabalhistas (eSocial).

Destacam-se, em nosso modelo, duas diferenças na forma de pagamento do financiamento, comparativamente à forma mais tradicional da experiência internacional, uma relacionada à coparticipação e a outra ao pagamento mínimo. Estas alteraçóes foram necessárias para sanar restriçóes legais existentes, conforme entendimento da Procuradoria Geral da Fazenda Nacional (PGFN). Com elas, diferentemente do modelo australiano, não será possível ex ante estabelecer que a dívida contraída junto ao Fies será suspensa quando a renda do egresso ficar abaixo de um valor mínimo anual.

Vale destacar que, no caso do Brasil, onde o financiamento é dirigido a instituiçóes privadas, a coparticipação dá ao aluno mais sensibilidade ao preço do curso, induzindo maior concorrência no setor.

Ademais, como o valor amortizado no Novo Fies depende da renda auferida pelo egresso, o prazo de quitação do débito será variável, determinado pelo valor efetivamente pago. Desta forma, diferentemente do que ocorria no antigo Fies, o valor da amortização não comprometerá percentual elevado da renda do trabalho do egresso, preservando sua capacidade de pagamento.

O modelo adotado é também mais robusto que o antigo na ocorrência de conjunturas econômicas adversas. Dado que o pagamento é uma proporção da renda, acomoda-se a eventuais perdas salariais, respeitando-se a capacidade de pagamento do egresso do ensino superior e mitigando o risco de default do compromisso assumido. Além disso, a existência de um Comitê Gestor e de um Plano Trienal possibilita adequar a oferta de vagas a conjunturas econômicas, contribuindo para uma maior sustentabilidade do programa.

Em relação à instituição do novo fundo garantidor (FG-Fies), o desenho desconcentrou o risco da União, compartilhando-o com as IES, e adequou a alavancagem do fundo ao nível de risco observado.

16. CHAPMAN, B. Income contingent loans in higher education financing. Bonn: IZA World of Labor, 2015. 
A contribuição da União se dará com aportes anuais ao longo dos primeiros anos de funcionamento do novo programa, a partir de 2018, o que contribuirá para o crescimento do patrimônio do fundo dada a inexistência de default nesses primeiros anos. No novo modelo, a IES passou a ser cotista do fundo, assumindo maior nível de risco, e sua contribuição passou a ser proporcional à inadimplência dos seus alunos durante as fases de utilização e amortização. Essa medida estimula as IES a serem criteriosas na seleção dos alunos e comprometidas com a qualidade do ensino, com consequência direta sobre a empregabilidade do aluno.

A vinculação do pagamento à renda do egresso e a existência do fundo garantidor possibilitam que a Uniáo receba parcela significativa do valor financiado, contribuindo para a sustentabilidade do programa e tornando possível o acesso contínuo de novos estudantes.

Relembra-se que, como no Brasil, diferentemente de outros países, o financiamento é destinado a vagas em instituiçóes privadas, é importante a existência de fundo garantidor, e que os agentes privados assumam parte relevante do risco.

A governança do Fies foi aprimorada pela instituição do Comitê Gestor do Fies (CG-Fies), constituído por membros dos ministérios da Educação, da Fazenda, do Planejamento, da Integração Nacional e da Casa Civil, e ouvindo representantes dos beneficiários do programa. O monitoramento contínuo e o fato de as decisóes serem colegiadas dotam a gestão de mais transparência, conhecimento e capacidade.

Como instrumento de governança, está também prevista a elaboração do Plano Trienal pelo CG-Fies, com revisóes anuais, aprimorando o planejamento e dando sustentabilidade ao Novo Fies e a seu fundo garantidor.

Outra alteração importante é a determinação para que, no momento da contratação, o aluno conheça o valor total do curso, o percentual financiado e a forma de reajuste das mensalidades. Assim, como em outros financiamentos, o financiado já saberá, no momento da contratação do empréstimo, o valor da dívida assumida. Além disso, as IES não poderão aumentar arbitrariamente as mensalidades no decorrer do curso, ficando restritas à atualização monetária contratualmente prevista.

A definição e a divulgação do valor total do curso previamente à contratação do financiamento permitirão que o estudante possa comparar os custos de cursos entre diversas IES, não somente no primeiro semestre, mas em todo o período letivo, proporcionando maior concorrência entre as IES e beneficiando o aluno.

Vale enfatizar, ainda, que o antigo Fies não era fiscalmente sustentável e concentrava os riscos do programa no setor público. No período de 2016 a 2018, a despesa primária com o Fies, que reflete os valores não pagos das concessôes de empréstimo pós 2010, já alcança cerca de R $\$ 6$ bilhóes por ano, valor muito próximo ao orçamento anual de $\mathrm{R} \$ 7,5$ bilhóes com ciência e tecnologia, em 2018. Com as mudanças já implementadas, mitiga-se o risco de passivos contingentes para o setor público e o risco de descontinuidade do programa por desequilíbrio financeiro.

\section{CONSIDERAÇÕES FINAIS}

Não há como prescindir do crédito estudantil subsidiado para estudantes de famílias de baixa renda, nem sempre atendidos pela concessão de bolsas de estudos. A manutenção de um programa de crédito educativo é ainda mais necessária em um país onde mais de $70 \%$ dos alunos de ensino superior estão matriculados em instituiçôes privadas (gráfico 1). 


\section{GRÁFICO 1}

Número de matrículas da rede privada (com Fies e sem Fies) e pública

(Em milhões)

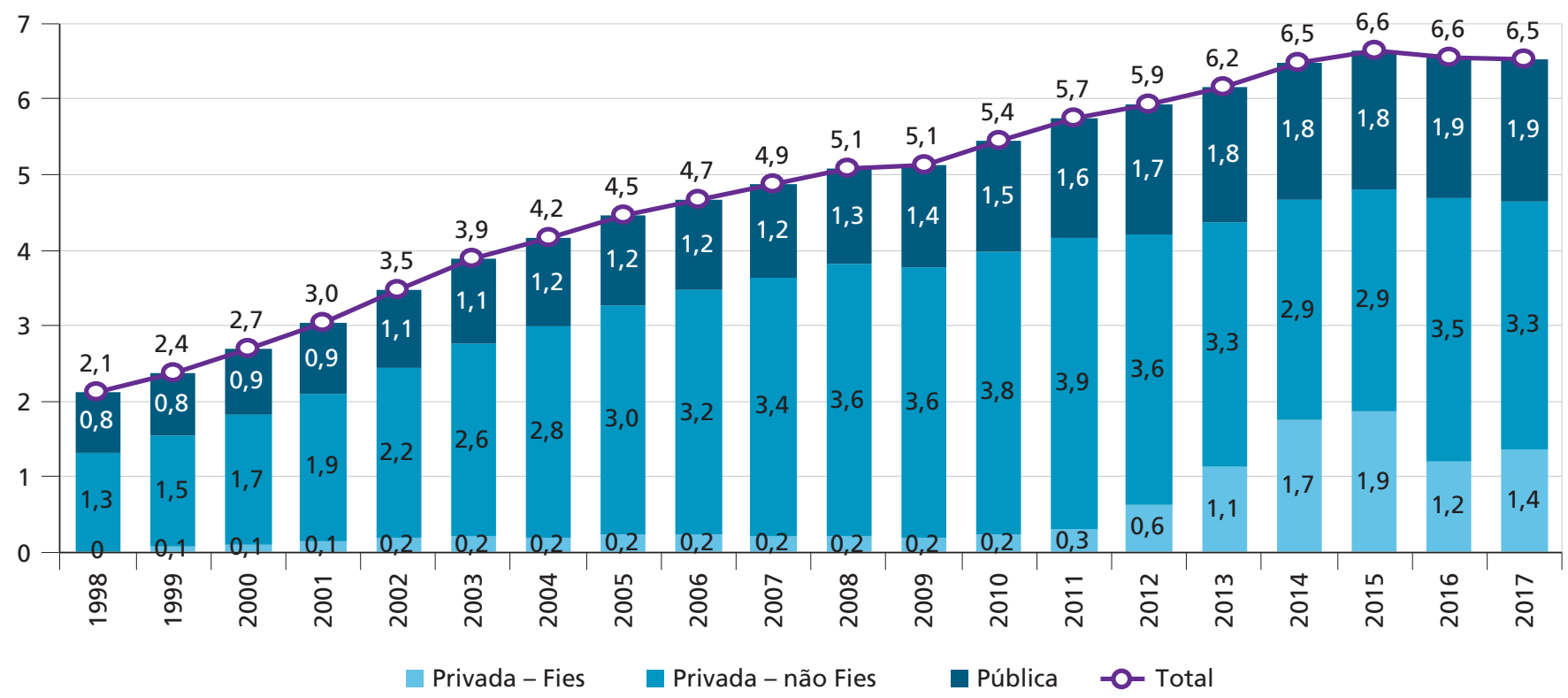

Fonte: Inep, SisFies e Caixa.

Obs: Fies privados foram considerados os contratos em utilização, observados de 2010 a 2015 e calculados para os outros anos, retirando dos ativos o percentural de cancelamentos/conclusão observado nos últimos anos.

Do exposto, percebe-se que as mudanças implementadas buscaram dar maior efetividade à política pública, tendo como principais objetivos tornar o programa fiscalmente sustentável e realinhar os incentivos entre os atores, respeitando a capacidade de pagamento do aluno e atribuindo mais responsabilidade às instituiçóes de ensino de forma a evitar a descontinuidade do programa. 


\section{FUNDO DE FINANCIAMENTO ESTUDANTIL (FIES): VICISSITUDES E DESAFIOS}

Vicente de Paula Almeida Júnior ${ }^{1}$

Pedro Antônio Estrella Pedrosa

\section{INTRODUÇÃO}

Este artigo resume as principais alteraçóes ocorridas no Fundo de Financiamento Estudantil (Fies) a partir da Lei no 13.530/2017 e apresenta alguns desafios e oportunidades de melhorias para o programa a partir da nova lei.

O texto está organizado em três seçôes. A primeira situa o Fies em conjunto com o Programa Universidade para Todos (Prouni), as Bolsas de Certificação de Entidades Beneficentes de Assistência Social (CEBAS) e o Programa de Estímulo à Reestruturação e ao Fortalecimento das Instituiçóes de Ensino Superior (Proies), todos empreendidos pelo Ministério da Educação (MEC) para favorecer o acesso à educação superior no país, especificamente ao ensino superior privado, responsável por 75,3\% do total das matrículas ofertadas nesse nível de ensino. A segunda seção apresenta as linhas gerais do novo financiamento estudantil. Por sua vez, a terceira esboça os principais desafios e oportunidades de melhorias para o aperfeiçoamento da política educacional em curso.

\section{FIES NO CONTEXTO DOS PROGRAMAS DE ACESSO À EDUCAÇÃO SUPERIOR NO BRASIL}

Dados do Censo da Educação Superior 2017, divulgados pelo Instituto Nacional de Estudos e Pesquisas Educacionais Anísio Teixeira (Inep), mostram que o percentual de matrículas na rede privada de ensino superior com algum tipo de financiamento e/ou bolsa no Brasil alcançou 46,3\% do total de matrículas do setor (gráfico 1).

\section{GRÁFICO 1}

Matrículas na rede privada com algum tipo de financiamento/bolsa - Brasil (2009-2017)

(Em \%)

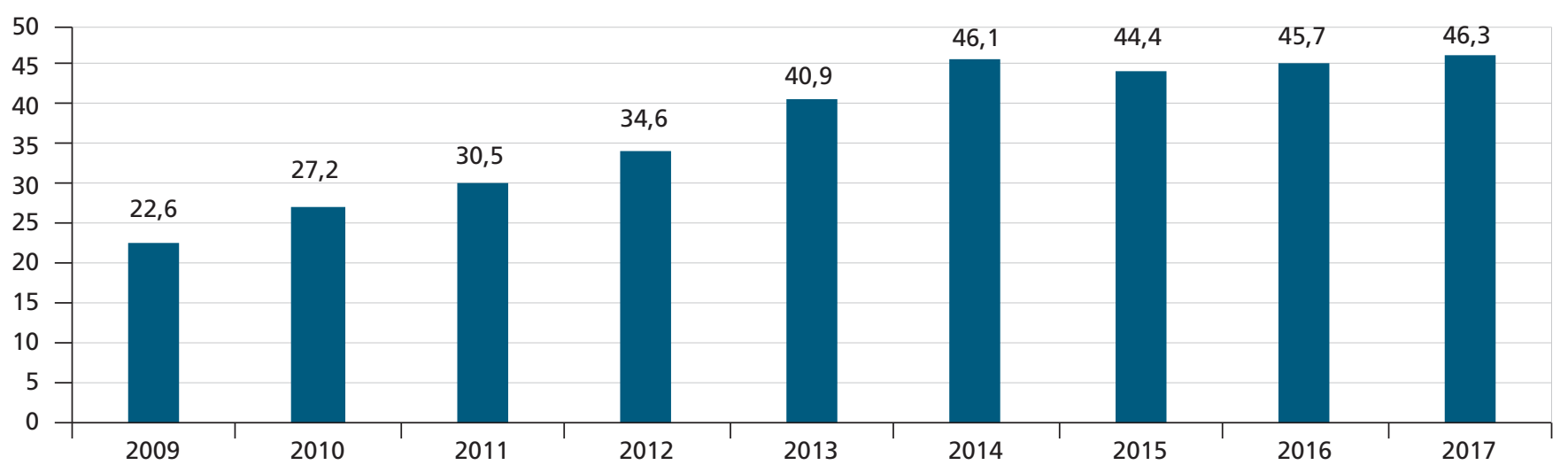

Fonte: Inep/MEC.

Elaboração dos autores.

1. Diretor de Políticas e Programas de Educação Superior do Ministério da Educação (DPPES/SESu/MEC). Pós-doutor em educação superior pela Universidade de São Paulo (USP). Doutor em educação pela Universidade Estadual de Campinas (Unicamp). E-mail: <vicente.junior@mec.gov.br>.

2. Diretor na Diretoria de Gestão de Fundos e Benefícios (Digef); Fundo Nacional de Desenvolvimento da Educação (FNDE) do MEC. Mestre em economia e previdência pela Universidade de Brasília (UnB).E-mail: <pedro.pedrosa@fnde.gov.br>. 
Entre os programas citados, o Prouni e o Fies se destacam na realidade educacional brasileira por abrirem as possiblidades de acesso ao ensino superior privado. O gráfico 2 mostra a evoluçáo de ambos ao longo do tempo em relação às matrículas da rede privada.

GRÁFICO 2

Matrícula na rede privada por tipo de financiamento/bolsa - Brasil (2009-2017)

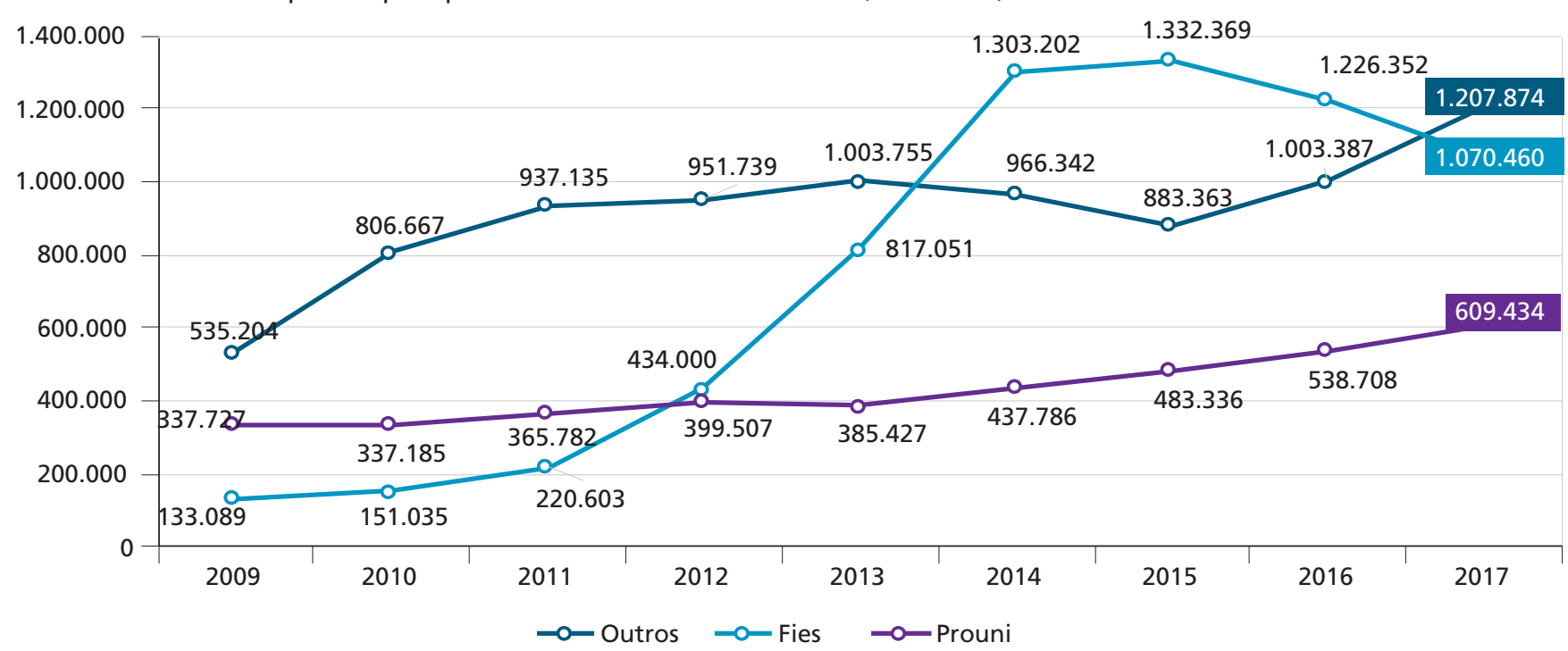

Fonte: Inep/MEC.

O Prouni, instituído pela Lei no 11.096/2005, é um programa de concessão de bolsas de estudo integrais e parciais de cinquenta por cento $(50 \%)$ para estudantes brasileiros de cursos de graduação em instituiçóes privadas de ensino superior com avaliação positiva no Sistema Nacional de Avaliação da Educaçáo Superior (Sinaes). Como contrapartida à adesão ao programa, as instituiçôes ficam isentas de alguns impostos e contribuiçóes ${ }^{3}$ no período de vigência do termo de adesão. O programa não se configura como uma ação orçamentária, isto é, não tem impacto sobre o orçamento consignado anualmente para o MEC.

O Fies, por sua vez, tem impacto considerável sobre o orçamento da União, como já visto neste Radar. Além da perspectiva orçamentária, o programa tem enorme relevância acadêmica. Conforme os dados do Censo da Educação Superior 2017, o Fies representa 37,1\% do total das matrículas da rede privada, enquanto o Prouni 21,1\% e outros programas fomentados pelo MEC, 41,8\% das matrículas.

As modificaçôes trazidas pela Lei n⿳⺈ $13.530 / 2017$ e pelo Comitê Gestor do Fundo de Financiamento Estudantil (CG-Fies) remodelaram o programa, ampliando modalidades, possibilitando juro real zero a estudante com renda de até 3 salários mínimos e escala de financiamento variada conforme a renda familiar do candidato, além de implementar novo modelo de gestão e governança.

\section{NOVO FUNDO DE FINANCIAMENTO ESTUDANTIL (FIES): LINHAS GERAIS}

Até o primeiro semestre de 2015, para obter o financiamento estudantil por meio do programa, bastava o estudante acessar o sistema do MEC em qualquer período do ano. Mediante o preenchimento de um cadastro no sistema, informava os seus dados pessoais e financeiros e indicava a instituição e curso para o qual pretendia

3. Isenções de Impostos e contribuições no Prouni: i) imposto de renda das pessoas jurídicas; ii) contribuição social sobre o lucro líquido; iii) contribuição social para financiamento da seguridade social; e iv) contribuição para o Programa de Integração Social. 
contratar o empréstimo. Após conclusão do cadastro, o estudante se dirigia à instituição de ensino escolhida e, com as informaçóes já validadas, comparecia ao agente financeiro (banco) para celebrar o contrato.

A partir do segundo semestre de 2015, adotou-se novos parâmetros para ingresso de estudantes interessados em obter o financiamento, passando a ser exigido nota mínima de 450 (quatrocentos e cinquenta) pontos na média do Exame Nacional do Ensino Médio (Enem) e nota diferente de zero na redação. Além disso, ocorreram outras mudanças no período: disponibilização de vagas conforme previsão em Lei Orçamentária Anual (LOA); concessão do financiamento a estudantes com renda familiar mensal bruta per capita de até dois e meio salários mínimos; prioridade na oferta de financiamento em cursos com conceitos positivos no Sistema Nacional de Avaliação da Educação Superior (Sinaes); prioridade na oferta de financiamento em cursos nas áreas de formação de professores (licenciatura, pedagogia e normal superior), saúde e engenharias.

A partir do segundo semestre de 2016, as diretrizes e as regras para a sustentabilidade do programa, notadamente sobre os processos de adesão das entidades mantenedoras e processo seletivo de estudantes, foram aprofundados e redesenhados sob novas bases, permitindo mais modalidades de financiamento, adoção de critérios mais objetivos e auditáveis e clareza nas responsabilidades dos atores envolvidos (Órgãos de governo, agentes financeiros, instituiçôes de ensino e estudantes). Portanto, não se restringem ao aspecto fiscal, a fim de garantir a sua eficiência e controle, mas também em relação à própria política educacional e governança do programa, melhorando as informações e condiçôes de acesso para os estudantes e instituições participantes.

Nesse quadro e dado que o programa envolve vários setores de governo e da sociedade, o CG-Fies disciplina as regras e diretrizes do programa, estabelecendo o orçamento e o quantitativo de vagas para determinado exercício fiscal. As vagas são distribuídas conforme um algoritmo cujas variáveis consideram a demanda por ensino superior apurada por mesorregião, áreas prioritárias (formação de professores, saúde, engenharias e ciências da computação) e conceito de qualidade do curso.

O processo de adesão das entidades mantenedoras inicia-se a partir de calendário previamente divulgado, momento em que as instituiçóes ofertam um certo quantitativo de vagas para o programa. Em cada instituição, limita-se as vagas financiáveis às autorizadas por processos de regulação e avaliação coordenados pelo MEC, e pelo conceito de qualidade do curso participante.

No novo processo de seleção, os estudantes inscrevem-se e concorrem a uma das vagas a partir da nota obtida no Enem. De acordo com as suas preferências ou escolhas (por estado, município, curso, conceito de curso, área e subárea de conhecimento) os estudantes definem no processo de inscrição o curso e a instituição de seu desejo, obtendo no próprio sistema informaçóes claras sobre os valores globais do curso, comparativamente com outros cursos e instituiçôes, mensalidades, parcelas, juros, qualidade do curso pretendido e número de vagas disponíveis. Os processos de adesão das instituiçóes e de seleção dos estudantes envolvem duas modalidades no Novo Fies.

A primeira modalidade é direcionada a estudantes com renda familiar bruta de até três salários mínimos per capita, e oferece melhores condiçóes de financiamento e uma série de outras melhorias na gestão e transparência do programa para os estudantes. Uma inovação trazida é a previsão de taxa de juros reais zero, enquanto a taxa de juros nominal fixada à época da publicação da norma era de 6,5\%.

Além disso, respeitando a capacidade de pagamento do estudante, o prazo e a forma de pagamento das prestaçóes do financiamento passou a ser mediante a vinculação do valor da prestaçáo à renda efetiva do financiado. $\mathrm{O}$ valor da prestação foi calculado de maneira proporcional ao salário bruto do estudante financiado, mediante retenção diretamente na fonte pagadora e recolhimento direto ao Fies. Assim, o período de amortizaçáo passou a depender da renda do estudante - medida que constituiu importante mecanismo de mitigação da inadimplência. Aliada a essas medidas, o agente financeiro, de acordo com as diretrizes do MEC e do CG-Fies, definiu possibilidade de pactuar medidas de estímulo à liquidação ou reescalonamento das dívidas vencidas, visando a assegurar o retorno dos capitais emprestados. 
A segunda modalidade do Novo FIES, denominada de P-FIES, é constituída parcialmente por recursos públicos (via fundos constitucionais regionais e Banco Nacional de Desenvolvimento Econômico e Social BNDES) e operacionalizada por instituiçôes financeiras autorizadas a funcionar pelo Banco Central do Brasil, sejam elas públicas ou privadas, que passam a assumir integralmente o risco de crédito das operaçóes e o custo de captação (taxa de longo prazo - TLP) e pode atender, na forma da regulamentação, estudantes com renda bruta familiar mensal de até cinco salários mínimos per capita, contando com garantia exclusivamente privada.

No contexto das alteraçóes voltadas à sustentabilidade do Fies, está a eliminação da fase de carência do financiamento, período compreendido entre a fase na qual o estudante está frequentando a graduação e a fase de amortização, quando o estudante começa a pagar as prestaçôes do empréstimo. Como o estudante já efetua durante o curso o pagamento às instituições de ensino da parcela da mensalidade náo financiada pelo programa, o objetivo da medida é que mantenha a disciplina de pagamentos imediatamente após a conclusão do curso. Adicionalmente, a medida contribui para que os recursos emprestados comecem a retornar ao Fundo mais cedo, pois o prazo de carência existente antes era de dezoito meses.

Durante o período do curso, como forma de estimular o efetivo acompanhamento da evoluçáo dos preços praticados pelas instituiçóes de ensino, os estudantes pagarão diretamente ao agente financeiro o valor correspondente à parcela das mensalidades não financiadas (coparticipação). Em substituição ao pagamento trimestral de juros de até R \$ 150,00 praticado anteriormente, o estudante irá efetuar o pagamento do valor equivalente às despesas operacionais do agente financeiro e de seguro prestamista para cobertura da totalidade do contrato.

O novo Fundo Garantidor do Fies (FG-Fies) teve integralização inicial da União e participação das entidades mantenedoras das instituiçóes de ensino. Inicialmente, a participação destas foi fixada em $13 \%$ do valor dos encargos educacionais financiados, participação esta que variará no futuro de acordo com o patamar de inadimplência dos egressos de cada instituição de ensino. O Fundo tem por objetivo a complementariedade de renda dentro do prazo de amortização e a garantia do risco de crédito dos financiamentos. Os estudantes com renda familiar mensal bruta per capita de até um salário-mínimo e meio têm a cobertura exclusiva do FG-Fies e os estudantes com renda superior precisarão indicar fiador. $\mathrm{O}$ aumento da participação no risco de crédito por parte das instituiçóes de ensino potencializou os efeitos da política ao facilitar o acesso dos estudantes de menor renda aos cursos de nível superior, contribuindo para a formação de mão de obra qualificada, cada vez mais necessária para obtenção de um crescimento sustentável de médio e longo prazos, visto que haverá a certeza de retorno dos capitais investidos pelo Fies, pois eventuais perdas serão assumidas exclusivamente pelo FG-Fies.

\section{DESAFIOS E OPORTUNIDADES DE MELHORIA}

Passado o esforço inicial da implementação das novas mudanças do programa, torna-se necessário começar a pensar nas possíveis melhorias que podem ser feitas para aperfeiçoar a política pública. Não se deve perder de vista o objetivo de proporcionar o acesso dos estudantes ao crédito estudantil e de se manter náo-pagamento em níveis sustentáveis.

O primeiro estudo técnico que deve ser feito é sobre o impacto fiscal de se retirar a parcela de pagamento mínimo dos estudantes recém-formados que ainda não possuem uma renda formal. Este ajuste aproximaria o novo Fies das boas práticas internacionais, pautadas em empréstimos com amortizaçóes contingentes à renda futura (ECRs).

Outro ponto que deve ser alvo de melhorias é qualidade da carteira dos financiamentos da modalidade antiga. Atualmente, os índices de inadimplência já passaram dos $50 \%$ para os estudantes em fase de amortização. A grande preocupação é que quando a maior parte da carteira alcançar a fase de pagamento, o prejuízo para a União pode passar dos R \$ 30 bilhóes. Nesse sentido, os agentes financeiros do programa devem melhorar as formas 
de cobrança, utilizando-se das novas tecnologias disponíveis no mercado (SMS, e-mails e centrais telefônicas), para aproximar dos alunos inadimplentes, principalmente nos primeiros dias de atraso.

Necessita-se também desenvolver novos planos de renegociaçáo de dívidas, com opçóes de reparcelamento e refinanciamento, nos moldes de modelos bancários de crédito de varejo. Atualmente, a única maneira que o aluno inadimplente possui de renegociar a sua dívida é com o pagamento integral do seu saldo, à vista. O objetivo de uma campanha de renegociação é conseguir trazer os alunos que náo possuíam renda no momento do início da fase de pagamento, mas que agora possuem renda formal.

Por fim, deve-se buscar o fortalecimento das modalidades do P-FIES, com atuação de bancos comerciais. Essa fonte alternativa de recursos é essencial para expandir a base de financiamento educacional no país. A atuação de bancos regionais, que conhecem as particularidades do mercado de trabalho da regiáo, é essencial para ampliar a base de estudantes nas regióes mais carentes. Vale reforçar que nessa modalidade o governo federal não possui o risco na operação.

Destaque-se que o FIES, reformulado sob novas bases, juntamente com o Prouni, o Sistema de Seleção Unificada (Sisu) e a Lei de Cotas, tem importante papel na indução de políticas para o acesso e a permanência em cursos superiores de contingente populacional que historicamente esteve excluído desse nível educacional. 



\section{PRONATEC 2.0: UMA PROPOSTA DE REFORMULAÇÃO FUNDAMENTADA EM FINANCIAMENTOS CONTINGENTES À RENDA ${ }^{1}$}

Paulo Meyer Nascimento

\section{INTRODUÇÃO}

O Programa Nacional de Acesso ao Ensino Técnico e Emprego (Pronatec), instituído por lei em fins de 2011, é, ainda hoje, a política federal de fomento à educação profissional e tecnológica no país. Seis iniciativas foram, à época, integradas ao programa, mas só uma realmente inédita: a oferta de vagas gratuitas por meio de bolsas-formação. ${ }^{3}$ Foi esta a iniciativa que deu impulso ao Pronatec em seus anos iniciais, chegando a representar mais de dois terços do que fora pago pelo programa. Não à toa, costuma a bolsa-formação ser confundida com o próprio Pronatec.

Com o ajuste fiscal iniciado em 2015, o volume de recursos efetivamente destinados à bolsa-formação foi bastante reduzido, afetando também, por conseguinte, o próprio Pronatec. Embora o orçamento autorizado para as bolsas-formação tenha crescido marginalmente naquele ano, os desembolsos efetivamente feitos em 2015 foram, em termos reais, 59\% menores do que em 2014. A bolsa-formação seguiu sendo a iniciativa de maior vulto do Pronatec, mas também a mais afetada pelos cortes que se sucederam desde então. De lá para cá, não houve nenhuma mudança significativa nas formas de financiamento da educação profissional e tecnológica do país.

Em tempos de restrição fiscal, a oferta de vagas gratuitas de cursos técnicos e de formação inicial continuada (FIC) perde força e compromete a abertura de 5 milhóes de novas vagas, meta estipulada para o horizonte de tempo do Plano Plurianual (PPA) 2016-2019. Para o horizonte do próximo PPA são necessárias, portanto, alternativas de financiamento que estejam além do orçamento federal e que ajudem a contornar minimamente a carência de recursos públicos. Um caminho que se coloca é criar condiçóes para que floresçam alternativas de financiamento no mercado privado.

Neste sentido, vale destacar que, como desdobramento do Pronatec, foi regulamentada, em 2012, a extensão do Fundo de Financiamento Estudantil (Fies) a cursos técnicos e a cursos FIC, para a qual já havia previsão legal desde 2010. A regulamentação adveio com a Portaria no 270/2012. Chamou-se inicialmente de Fies empresa a linha de crédito imaginada para as empresas financiarem cursos FIC de seus colaboradores, e de Fies técnico a linha para o próprio trabalhador obter financiamento para seu curso técnico ou FIC. A nova Lei do Fies, aprovada em dezembro de 2017, incorpora previsão expressa de duas modalidades semelhantes, denominando de Fies-Trabalhador a linha disponível para trabalhadores financiarem, em caráter individual, cursos FIC, cursos técnicos e cursos superiores, e de Fies-Empresa a linha disponível a empresas interessadas em financiar tais cursos para seus colaboradores.

Enquanto havia fartura de oferta de bolsas formação, nenhuma das duas linhas de crédito mostraram-se viáveis. Mesmo com significativa redução da oferta de bolsas-formação, o momento econômico por que tem passado o país dificulta o deslanche dessas duas iniciativas. Isto porque requerem, de um lado, aportes de recursos

\footnotetext{
1. A proposta cujas linhas gerais são discutidas no presente texto é também delineada no Texto para Discussão número 2220 do Ipea, disponível em: <https://bit.ly/2DNBTBT>; e em NASCIMENTO, P. M. O Pronatec em tempos de ajuste fiscal. Desafios do desenvolvimento, ano 13, ed. 87, 17 jun. 2016. Disponível em: <https://bit.ly/2Qny2wE>. Acesso em: 2 out. 2018.

2. Técnico de planejamento e pesquisa na Diretoria de Estudos e Políticas Setoriais de Inovação, Regulação e Infraestrutura do Ipea (Diset) do Ipea.

3. A bolsa-formação é uma iniciativa disponível para cursos presenciais oferecidos nas escolas públicas federais, estaduais e municipais, nas unidades de ensino do Serviço Nacional de Aprendizagem Industrial (Senai), do Serviço Nacional de Aprendizagem Comercial (Senac), do Serviço Nacional de Aprendizagem Rural (Senar) e do Serviço Nacional de Aprendizagem do Transporte (Senat), em instituições privadas de ensino superior e de educação profissional técnica de nível médio. Por meio dela o beneficiário estuda gratuitamente em cursos técnicos concomitantes ou subsequentes ao ensino médio (com mínimo oitocentas horas de duração) ou em cursos de formação inicial e continuada (FIC) ou de qualificação profissional (com mínimo de cento e sessenta horas de duração).
} 
públicos para conceder o financiamento e, de outro, disposição de trabalhadores e empresas a investirem em um momento em que o nível geral de endividamento segue alto e o de confiança, baixo.

Sem embargo, ajustes no formato do Fies-Trabalhador e do Fies-Empresa os tornariam livres de subsídios governamentais e opções viáveis e atrativas para trabalhadores, empresas e investidores, liberando as bolsas-formação basicamente para a qualificação de pessoas que, por alguma condição específica, apresentem maior dificuldade de inserção no mundo do trabalho. Este texto apresenta instrumentos de financiamento contingente à renda como possíveis e promissores caminhos de reforma do Fies-Trabalhador, do Fies-Empresa e da própria bolsa-formação.

\section{INSTRUMENTOS DE FINANCIAMENTO CONTINGENTE À RENDA COMO ALTERNATIVA PARA O PRONATEC}

Há, atualmente, em operação em alguns países um instrumento de financiamento que tem se mostrado bem-sucedido como política de crédito educativo. Os empréstimos com amortizaçóes contingentes à renda futura (ECRs) são uma modalidade de financiamento que dilui as amortizaçôes ao longo da vida economicamente ativa do mutuário, em prestaçóes definidas de acordo com sua renda futura e cobradas pelos sistemas de tributação ou de recolhimentos de contribuiçôes previdenciárias. ${ }^{4}$

Em paralelo aos ECRs propriamente ditos, um outro tipo de financiamento contingente à renda, mais próximo a instrumentos financeiros de capital próprio, poderia ajudar a dinamizar o financiamento privado da educação profissional e tecnológica. Tais instrumentos consistiriam em contratos entre particulares em que estudantes têm seus estudos financiados por algum ente privado em troca de um percentual fixo de sua renda futura por determinado período de tempo. Alguns chamam este tipo de financiamento contingente à renda de contratos de capital humano, ${ }^{5}$ enquanto outros o designam de acordos de partilha de renda. ${ }^{6}$

O ente privado que financiasse dessa maneira um curso para alguém não estaria emprestando-lhe dinheiro, e sim investindo nessa pessoa. E investe por acreditar que ela obterá retornos econômicos significativos em sua vida profissional futura, o que propiciaria ao investidor auferir dividendos a partir do seu investimento.

Como em toda aplicação financeira, há aí riscos para o investidor: a pessoa em quem investiu talvez não obtenha rendimentos futuros tão elevados que compense o investimento. A outra face da moeda é que os rendimentos futuros talvez ensejem dividendos que suplantem em muito o valor investido.

Para o estudante-trabalhador há a garantia de que só incorrerá em obrigação pecuniária em proporção fixa de seu rendimento futuro, e por tempo determinado. Não há obrigação de prestar qualquer tipo de serviço ao investidor. Não se trata de uma relação de trabalho forçado, e sim de uma captação de recursos mediante promessa de remuneração futura vinculada aos retornos econômicos que o estudante vier a usufruir durante determinado período posterior aos seus estudos. A pessoa continua com liberdade para escolher se, quando, onde, para quem e no que pretende trabalhar. Porém, como não se trata de um empréstimo, e sim de um investimento, quem viesse a obter altos retornos futuros não poderia contestar um desfecho em que a remuneração cabida ao investidor supere o valor presente do capital investido. O que há desde o início é um contrato entre particulares estabelecendo como remuneração pelo investimento de uma das partes na formação da outra a transferência de um percentual da renda desta durante determinado período de tempo no futuro.

4. Os ECRs são abundantemente discutidos em outros textos desta edição do boletim Radar.

5. Ver PALACIOS, M. Investing in human capital: a capital markets approach to student funding. Cambridge: Cambridge University Press, 2007.

6. Ver reportagem (em inglês) publicada na revista inglesa The Economist em julho de 2018 e disponível em: <https://econ.st/2Ri8YIJ>. Acesso em: 2 out. 2018. 


\section{LINHAS GERAIS DE UMA ALTERNATIVA DE REFORMA DO PRONATEC}

No formato ora proposto, empregadores financiam a qualificação de colaboradores em cursos credenciados, tendo a garantia de que a Receita Federal futuramente recolherá um percentual da renda dessas pessoas por um prazo preestabelecido e lhes transferirá, na forma de compensação tributária, de títulos públicos ou mesmo por crédito em conta corrente. Um mecanismo assim poderia viabilizar o Fies-Empresa e o Fies-Trabalhador, explicitaria o caráter de investimento da formaçáo profissional e teria o potencial de remover um dos principais motivos mormente apontado como inibidor desse tipo de decisáo por parte das empresas: o receio de investir em seus colaboradores para depois vê-los capturados por concorrentes, beneficiando ao final mais estes do que a si mesmas com os eventuais ganhos de produtividade propiciados pela qualificação custeada.

O financiamento poderia também partir de outros entes privados que não necessariamente as empresas diretamente, como fundaçôes, fundos de investimento, organizaçôes não governamentais ou quaisquer entidades do terceiro setor, vinculadas ou não ao setor produtivo, desde que utilizassem recursos próprios para esse fim. Esta poderia ser uma opçáo de investimento até mesmo para pessoas físicas, como uma figura análoga à dos investidores-anjos de startups.

Perceba-se que o modelo ora proposto tem como objetivo compartilhar o custo da qualificaçáo profissional no âmbito do próprio setor privado - de um lado, financiadores, em geral os próprios empregadores e suas entidades representativas; de outro, trabalhadores. Esses são os agentes mais bem informados sobre as carências do mercado de trabalho e sobre o potencial de crescimento profissional de cada trabalhador. Regular instrumentos capazes de transformar em investimentos o financiamento da formação continuada é, pois, uma maneira eficiente de alocar recursos nessa modalidade da educação.

Deveria ser evitado nesse formato, contudo, que o governo (leia-se, o contribuinte) arcasse com as perdas dos entes privados decorrentes de baixos rendimentos dos trabalhadores em cuja qualificação investiram. Tal como em modelos de ECR propriamente ditos, nos quais perdas assim podem ocorrer quando a renda futura não se revela suficientemente alta para viabilizar o pagamento integral do empréstimo no prazo máximo estabelecido, em contratos de capital humano o investimento na formaçáo de uma pessoa pode não render o esperado.

Para que a modalidade aqui proposta funcione de maneira eficaz e eficiente, tal risco remanescente deve recair sobre quem investe na qualificação profissional do trabalhador, sejam pessoas físicas, empresas, fundos de investimento, organizaçóes do terceiro setor ou outros entes privados que se interessassem pela iniciativa. Isto quer dizer que a remuneraçáo do investidor deva ser equivalente à parcela da renda definida em contrato e concedido somente à medida que os pagamentos sejam efetivamente coletados - o governo se limitaria a aferir a renda futura do trabalhador qualificado, cobrar-lhe o que é devido e transferir de alguma maneira ao investidor o pagamento efetivado pelo trabalhador. Isto seria importante tanto para manter o caráter de investimento da iniciativa quanto para compartilhar com esses investidores a responsabilidade pela qualidade da qualificaçáo do trabalhador - até porque os contratos de capital humano, contrariamente aos ECRs propriamente ditos, possibilitam que os reembolsos durante o prazo acordado eventualmente suplantem bastante o valor presente do investimento inicial. Se for o contribuinte quem arque com o risco do investimento, o incentivo poderá ser de financiar cursos técnicos e FIC indiscriminadamente, inclusive em acordo com estabelecimentos de ensino, pois haveria uma receita garantida para os investidores.

Sendo que os incentivos do investidor são os potenciais retornos financeiros, uma ferramenta assim tenderia a concentrar os investimentos nos estudantes com melhor potencial de desempenho e interessados nos cursos que costumam engendrar as melhores perspectivas de retorno econômico. Daí entấo a relevância de manter bolsas-formação direcionadas a públicos específicos, como jovens em busca de qualificação para o primeiro emprego, desempregados em busca de requalificação profissional, beneficiários do Bolsa Família e empreendedores. Poderiam ser mantidas como bolsas ou transformadas em ECR, em linha com o uso de 
financiamentos contingentes à renda como ferramenta do que alguns autores chamam de política pública de gestão de risco. ${ }^{7}$

Entidades privadas poderiam vislumbrar os contratos de capital humano também como instrumentos atraentes para financiar bons estudantes em cursos de graduação e de pós-graduação. Haveria, portanto, grande potencial de disseminação do instrumento, especialmente entre entidades privadas que costumam conceder bolsas de estudo. Ressalte-se, porém, que os ECRs propriamente ditos tendem a ser mais eficazes para financiar em larga escala estudantes de cursos superiores e que nenhum instrumento de financiamento contingente à renda torna prescindível financiamento público à educação. De todo modo, são mudanças que poderiam ser mais estudadas como alternativas para reerguer o Pronatec, com potenciais ganhos de produtividade sistêmica se, e à medida que, se espraiassem pela economia novos investimentos empresariais em capital humano. 


\section{EPÍLOGO: FINANCIAMENTOS CONTINGENTES À RENDA TÊM FUTURO NO BRASIL?}

Paulo Meyer Nascimento ${ }^{1}$

\section{INTRODUÇÃO}

Acesso gratuito ao ensino superior é frequentemente colocado como condição inegociável por quem valora educação como direito e a percebe como meio de empoderamento das pessoas e de suas comunidades. Mesmo para quem enfatiza o ensino superior como investimento em capital humano, gratuidade no ponto de uso é condição necessária para que as portas da universidade estejam abertas a quem não teria condiçóes financeiras para pagar um curso superior. Excluir quem não pode pagar é restringir liberdades individuais e limitar o desenvolvimento humano ${ }^{2}$ de um país.

Gratuidade irrestrita, contudo, também traz problemas. Mesmo incompleta, a transição para a gratuidade no Chile já exibe sinais de redução do investimento total nas instituiçôes de ensino superior (IES) e perspectiva de queda de qualidade e de atrofia da parcela do sistema tornada gratuita, o que tenderá a levar à exclusão dos mais pobres do ensino superior. ${ }^{3} \mathrm{Na}$ Argentina, o acesso irrestrito e gratuito a todos que possuam certificado de ensino médio impóe às universidades públicas matricular mais ingressantes do que sua capacidade instalada permite e, ao mesmo tempo, conviver com baixíssimas taxas de conclusão de curso. ${ }^{4} \mathrm{Na}$ Grécia, o não reconhecimento oficial de cursos pagos ${ }^{5}$ atrofia o sistema e obriga muitos gregos a buscar formação superior em outros países.

No Brasil, a gratuidade irrestrita, aliada às dificuldades legais impostas à captação de recursos externos, mantém as universidades públicas em perene estado de precarização financeira, evidenciada com mais força sempre que crises fiscais reduzem as fontes de financiamento público. Isso restringe o crescimento das IES públicas e torna o ensino superior majoritariamente privado no país.

Problemas dessa ordem exigem soluçôes complexas que também envolvem discutir financiamento à pesquisa e à extensão, autonomia universitária e os riscos e oportunidades relacionados ao financiamento privado da educação. Não obstante, parte da solução passa pela forma como a gratuidade de acesso é garantida. Dito isto, gratuidade para o estudante não implica, necessariamente, banir investimento privado e depender unicamente de recursos públicos. Os exemplos dados ajudam a ilustrar o quanto universalizar ensino superior com qualidade é particularmente difícil para países de renda média.

Significa, então, defender a cobrança generalizada de mensalidades, concedendo bolsas aqui e ali e disponibilizando empréstimos estudantis, como propôs o Banco Mundial ao governo brasileiro em 2017? ${ }^{6}$ Não. Empréstimos convencionais impulsionaram em todo o mundo o financiamento público a estudantes pós-secundários nas últimas sete décadas, mas seu esgotamento já é nítido em muitos países, inclusive no Brasil.

\footnotetext{
1. Técnico de planejamento e pesquisa na Diretoria de Estudos e Políticas Setoriais de Inovação e Infraestrutura (Diset) do Ipea.

2. Aqui entendido no sentido colocado por SEN, A. Desenvolvimento como liberdade. São Paulo: Companhia das Letras, 2000.

3. Como analisado em Lições da transição do Chile para a gratuidade no ensino superior, texto presente neste Radar.

4. FANELLI, A. G.; DEANE, C. A. Abandono de los estudios universitarios: dimensión, factores asociados y desafíos para la política pública. Revista Fuentes, n. 16, p. 85-106, fev. 2016.

5. A Constituição grega exige gratuidade em todos os estabelecimentos reconhecidos oficialmente, inclusive os privados. Cursos pagos não são, portanto, credenciados. Ver BROMME, T.; BRITTEN, B. Will Greece ever embrace private higher education? The Pie News, 3 fev. 2017. Disponível em: $<$ https://bit.ly/2PY6XQW>. Acesso em: 29 maio 2018.
}

6. BANCO MUNDIAL. Um ajuste justo: análise da eficiência e equidade do gasto público no Brasil. Brasília: The World Bank, 2017. 
O fim da gratuidade na Austrália (há três décadas) e na Inglaterra (há duas) tem mostrado ser possível compartilhar o financiamento dos estudos superiores entre o Estado e os egressos, isentando todos os estudantes de pagamentos durante os estudos ao mesmo tempo em que lhes garante que só contribuirão financeiramente com os custos do ensino se e na medida em que seus rendimentos futuros permitirem. Nos dois casos, viabilizou-se a expansão de vagas e de acesso. Esses países alcançaram isto por meio de amplos e bem-desenhados sistemas de empréstimos com amortizaçôes contingentes à renda futura (ECRs).

\section{O QUE É IMPRESCINDÍVEL PARA UM ECR AJUDAR A FINANCIAR O ENSINO CONCILIANDO JUSTIÇA SOCIAL E SUSTENTABILIDADE FISCAL?}

Em Financiamento do ensino superior: questôes conceituais e a experiência internacional, neste Radar, Bruce Chapman e Dung Doan ressaltam duas vantagens-chave dos ECRs sobre empréstimos convencionais.

1) Suavização do consumo e seguro contra choques de renda: como o valor das prestaçóes limita-se a um percentual preestabelecido da renda e, normalmente, há uma faixa de isenção de pagamento, os ECRs não estrangulam financeiramente seus mutuários nem pesam no orçamento em momentos de dificuldade financeira.

2) Redução dos custos de transação e aumento de eficiência: a coleta dos pagamentos via retenção na fonte minimiza o risco de não pagamento por ato deliberado do devedor e barateia a gestão do programa.

Para que essas vantagens sejam efetivas, algumas condiçóes são imprescindíveis. A primeira, que os pagamentos sejam de fato limitados a um percentual da renda do devedor, sem exigências de cobranças mínimas nem suplementares e preferencialmente garantindo-lhe algum horizonte de perdão da dívida, ainda que somente em caso de morte. ${ }^{7}$ A segunda, que a coleta dos pagamentos efetivamente utilize os mecanismos mais eficientes de cobrança de tributos.

Prestaçóes que não levam em conta a capacidade de pagamento do mutuário não devem ser parte de um ECR porque póem abaixo a sua característica de seguro contra choques de renda. ECR não é o mesmo que crédito consignado; seu objetivo é minimizar riscos tanto para quem empresta quanto para quem toma emprestado.

No financiamento estudantil, o caráter de seguro do ECR é particularmente importante, pois elimina justamente o risco de a dívida estudantil vir a comprometer o acesso do indivíduo a outros financiamentos. A possibilidade de ficar com o nome sujo pode afastar do ensino superior pessoas avessas ao risco, particularmente as mais pobres, para quem costumam ser maiores os custos de oportunidade envolvidos na decisão de estudar e também as incertezas acerca do próprio futuro e da qualidade dos cursos e das IES. Embora em um bom ECR inexista a figura da inadimplência e as sançôes dela decorrentes, a amortização pode vir a se estender por décadas, de forma que o não pagamento tende a se concentrar em indivíduos que realmente deveriam ser subsidiados. Faz-se necessário, portanto, que a Procuradoria Geral da Fazenda Nacional (PGFN) perceba que, diferentemente dos empréstimos convencionais, nos ECR o eventual não pagamento é um subsídio implícito. Sua incorporação no desenho do programa focaliza melhor o auxílio governamental do que subsidiar taxas de juros, prática usual em instrumentos de financiamento público que é totalmente desnecessária em um ECR.

A característica de seguro do ECR permite cobrar taxas de juros no mínimo iguais às de títulos públicos de longo prazo emitidos pelo Tesouro Nacional. Taxas de juros em um ECR aumentam o tempo necessário para amortizar a dívida, mas não o valor das prestaçóes, sempre vinculadas à renda. Subsidiar taxas de juros, portanto, reduz receita do governo sem trazer benefícios adicionais aos mais pobres. 
Tudo isso ainda reforça a necessidade de otimizar a coleta dos pagamentos. A Receita Federal do Brasil (RFB) não deixa nada a dever a seus congêneres de países desenvolvidos e dispóe de avançados meios para aferição da renda e cobrança de tributos. É essencial, portanto, seu envolvimento direto na coleta dos pagamentos de um ECR no Brasil. Isso poderia demandar alguma modificação na legislação infraconstitucional, a fim de incluir como atribuiçáo adicional da RFB a coleta de pagamentos de um ECR. Alternativamente, poder-se-ia optar por um modelo híbrido, instituindo-se um tributo cuja incidência cessasse uma vez transcorrido prazo e/ou atingido teto de contribuição preestabelecidos. Assim facilitar-se-ia o envolvimento da RFB na coleta dos pagamentos e evitar-se-ia que alguns egressos pagassem muito mais do que o custo de sua formação.

Cuidado maior seria necessário na definição das fontes de renda sobre as quais incidisse a alíquota desse tributo ou desse ECR. Ideal que incida sobre todas as fontes de renda pessoal (salários, pró-labore, rendimentos de aplicaçóes, lucros, dividendos, heranças), a fim de maximizar arrecadação, particularmente entre os não assalariados. Dificuldades para fazer dessa forma podem ser políticas, mas não técnicas nem operacionais.

\section{OS "QUASE ECRs" NA HISTÓRIA DO BRASIL}

Já houve discussões sobre ECR no Brasil antes mesmo de sua adoção na Austrália. Em um texto para discussão do Ipea publicado em $1979,{ }^{8}$ Alberto de Mello e Souza e Clóvis Faro propóem que as prestaçóes do Crédito Educativo (precursor do Fies) fossem contingentes à renda e que os egressos das universidades públicas passassem a pagar uma contribuição em moldes semelhantes. Todos os estudantes poderiam optar pelo ECR e sua amortização seria feita simultaneamente ao pagamento do imposto de renda. A recomendação de política, contudo, não foi adiante.

No âmbito do Sistema Financeiro de Habitação (SFH), buscou-se entre 1967 e 1988 proteger a capacidade de pagamento dos mutuários da casa própria equiparando a correção das prestações à dos salários. Isso não foi um ECR, pois os pagamentos não eram baseados na remuneração do indivíduo, não envolviam desconto automático em folha e continuavam sendo exigidos mesmo em caso de desemprego. Implicava, ademais, subsídios que se mostraram insustentáveis quando, na década de 1980, os reajustes salariais descolaram-se totalmente da inflação, gerando um rombo de fato pago pelo Tesouro Nacional até hoje, como ressalta Manoel Pires em Alguns comentários a respeito das reformas recentes no Fies e os desafios atuais, neste Radar. Em 1993, criou-se o Plano de Comprometimento da Renda (PCR), que facultava ao mutuário solicitar revisão do valor das prestaçóes sempre que ultrapassassem $30 \%$ da sua renda bruta. Não foi, contudo, capaz de reverter a crise do SFH, pois, além da burocracia envolvida nos processos de revisão das prestaçôes, os pagamentos não eram retidos na fonte e o risco de subdeclaração da renda era alto.

Voltando ao financiamento estudantil, duas propostas de emenda à Constituição (PEC) merecem destaque. Uma, já arquivada, ${ }^{9}$ propunha a criação de um fundo parcialmente financiado por uma contribuição social a ser paga por graduados e pós-graduados de IES públicas. Outra, ainda em tramitação, ${ }^{10}$ propóe retribuição individual dos egressos de IES públicas ou dos que tiveram seus estudos em IES privadas financiados pelo Estado. Um ECR ou um tributo do graduado caberia na regulamentação de ambas, se alguma dessas PECs houvesse sido aprovada.

8. Disponível em: <https://bit.ly/2CNLFSg>. Acesso em: 3 maio 2016. Posteriormente publicado como SOUZA, A. M.; FARO, C. Crédito educativo e ensino pago: sugestões para o financiamento do ensino universitário. Fórum Educacional, v. 4, n. 1, p. 3-17, 1980.

9. SCHONS, S. et al. Proposta de Emenda à Constituição (PEC) no 217, de 2003. Brasilia: Câmara dos Deputados, 2003. Disponível em: <https://bit.ly/2ERBChU>. Acesso em: 13 dez. 2015.

10. FIGUEIRÓ, R. et al. Proposta de Emenda à Constituição (PEC) no 34, de 2014. Brasília: Senado Federal, 2014. Disponível em: <https://bit.ly/2JrlUbW>. Acesso em: 13 dez. 2015. 


\section{AS REFORMAS RECENTES DO FIES TORNARAM-NO UM ECR?}

A Lei $n^{\circ}$ 13.530/2017 prevê pagamentos contingentes à renda no Fies, vinculando até $20 \%$ dos rendimentos brutos totais para pagamento do empréstimo estudantil. Regulamentaçóes posteriores limitam, por enquanto, a vinculação máxima a 13\% do salário e impóem a empregadores de mutuários do Fies coletarem esses pagamentos por meio do Sistema de Escrituração Digital das Obrigaçóes Fiscais, Previdenciárias e Trabalhistas (eSocial). Estas e outras novidades discutidas em alguns dos textos desta edição buscam reduzir inadimplência e retomar a sustentabilidade fiscal do Fies.

Vale ressaltar, contudo, que se exige coparticipação de todos estudantes beneficiados e pagamento mínimo dos egressos que deverem ao Fies e a quem o eSocial não alcance. Falta também clareza se e como serão aplicadas regras de perdão por decurso de tempo. Tudo isto compromete o caráter de seguro. Ademais, por mais que o eSocial represente avanços, perde-se uma grande oportunidade de maximizar pagamentos ao náo envolver a RFB na coleta e assim alcançar outras fontes de renda além dos salários. Ressalte-se, também, que a política de juro real zero gera custos fiscais desnecessariamente elevados e que as regras do programa ainda são de difícil compreensão. O Fies caminha para um ECR, mas questôes cruciais de proteção da pessoa, otimização da coleta e simplificação das regras ainda precisam ser sanadas para que seus objetivos sejam de fato alcançados.

\section{CONSIDERAÇÕES FINAIS}

O Brasil dispóe de condiçóes para implementar um amplo e bem-desenhado sistema de ECR para financiar estudantes de ensino superior, independentemente se matriculados em IES privadas ou públicas. Trata-se de uma política com potencial de, a médio e longo prazos, universalizar a gratuidade durante os estudos, mérito dos melhores sistemas do mundo. Isto porque um bem-desenhado ECR viabilizaria recursos adicionais para IES públicas, dando-lhe condiçóes de expansão, e daria sustentabilidade ao financiamento público a quem estuda em IES privadas, buscando a efetiva consecução do direito à educação sem desperdiçar recursos públicos. Simulaçóes feitas a partir de um painel com dados da Pesquisa Nacional por Amostra de Domicílios Contínua (PNAD Contínua) sugerem que, sem subsídios desnecessários e com o envolvimento da RFB na coleta dos pagamentos, um ECR com alíquotas correspondentes à metade das do imposto de renda, porém incidindo sobre toda a renda pessoal bruta aferível, permitiria arrecadar até mais de $90 \%$ dos montantes emprestados. ${ }^{11}$

Ainda que os desafios legislativos e operacionais não sejam pequenos, as condições técnicas e institucionais existem. O principal entrave para a adoção de um sistema de ECR baseado nas melhores práticas internacionais seria eminentemente político.

\footnotetext{
11. Resultado dos cenários mais otimistas entre os que foram simulados. Em todos os cenários, os valores dos empréstimos variavam de $R \$ 5$ mil a $R \$ 300$ mil, tomando-se como dívida média o valor de $\mathrm{R} \$ 50$ mil e assumindo-se desvio-padrão de 0,5. Mesmo nos cenários mais pessimistas, com juros altos e salários reais estáveis, o percentual de não pagamento foi sempre menor do que as taxas de inadimplência reportadas em $A$ reestruturação do Fies, neste Radar. Ver cenários completos em: NASCIMENTO, P. M. Modelling income contingent loans for higher education student financing in Brazil. 2018. Tese (Doutorado em Economia) - Universidade Federal da Bahia, Salvador, 2018.
} 

Ipea - Instituto de Pesquisa Econômica Aplicada

Assessoria de Imprensa e Comunicação

\section{EDITORIAL}

\section{Coordenação}

Ipea

\section{Revisão}

Editorar Multimídia

\section{Editoração}

Editorar Multimídia

Capa

Leonardo Hideki Higa

Imagens da Capa

Banco Freepik (freepik.com)

Projeto Gráfico

Renato Rodrigues Bueno

The manuscripts in languages other than Portuguese published herein have not been proofread.

\section{Livraria Ipea}

SBS - Quadra 1 - Bloco J - Ed. BNDES, Térreo

70076-900 - Brasília - DF

Tel.: (61) 20265336

Correio eletrônico: livraria@ipea.gov.br 




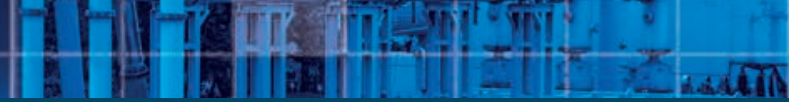

\section{Missão do Ipea}

Aprimorar as políticas públicas essenciais ao desenvolvimento brasileiro por meio da produção e disseminação de conhecimentos e da assessoria ao Estado nas suas decisões estratégicas.
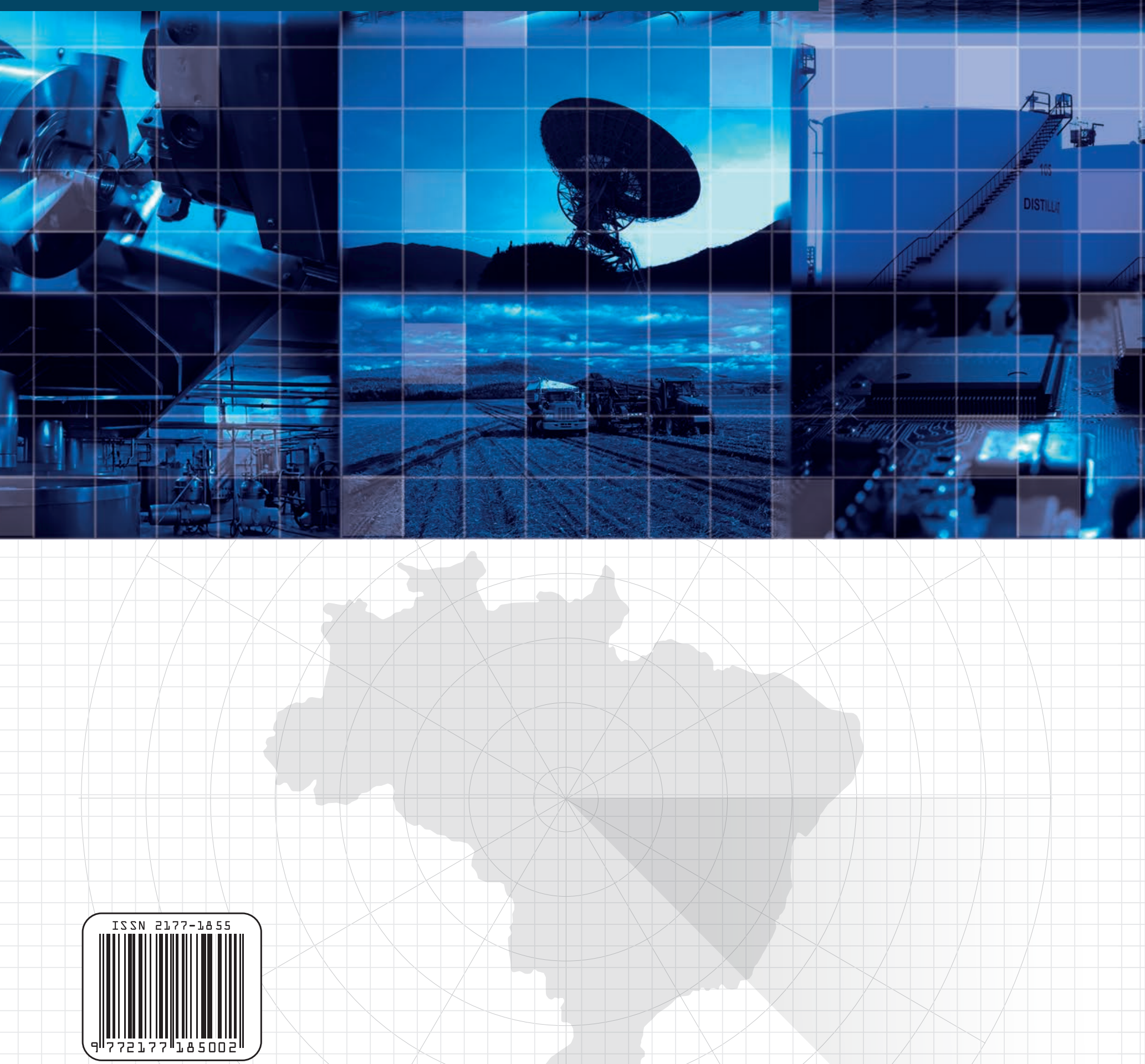